OPEN ACCESS

Edited by:

Kelvin To,

University of Hong Kong, Hong Kong

Reviewed by:

Man Lung Yeung,

University of Hong Kong, Hong Kong

Mahmoud Mohamed Shehata,

National Research Centre, Egypt

*Correspondence:

Sinosh Skariyachan

sinoshskariya@gmail.com;

sinosh-bt@dayanandasagar.edu

Specialty section:

This article was submitted to

Virology,

a section of the journal

Frontiers in Microbiology

Received: 28 October 2018

Accepted: 05 March 2019

Published: 26 March 2019

Citation:

Skariyachan S, Challapilli SB, Packirisamy S, Kumargowda ST and Sridhar VS (2019) Recent Aspects on the Pathogenesis Mechanism, Animal

Models and Novel Therapeutic

Interventions for Middle East

Respiratory Syndrome Coronavirus

Infections. Front. Microbiol. 10:569.

doi: 10.3389/fmicb.2019.00569

\section{Recent Aspects on the Pathogenesis Mechanism, Animal Models and Novel Therapeutic Interventions for Middle East Respiratory Syndrome Coronavirus Infections}

\author{
Sinosh Skariyachan*, Sneha Basavaraj Challapilli, Swathi Packirisamy, \\ Supreetha Toplar Kumargowda and Vaishnavi Sneha Sridhar
}

R\&D Centre, Department of Biotechnology, Dayananda Sagar College of Engineering, Bengaluru, India

Middle East Respiratory Syndrome Coronavirus (MERS-CoV) is an emerging zoonotic virus considered as one of the major public threat with a total number of 2298 laboratory-confirmed cases and 811 associated deaths reported by World Health Organization as of January 2019. The transmission of the virus was expected to be from the camels found in Middle Eastern countries via the animal and human interaction. The genome structure provided information about the pathogenicity and associated virulent factors present in the virus. Recent studies suggested that there were limited insight available on the development of novel therapeutic strategies to induce immunity against the virus. The severities of MERS-CoV infection highlight the necessity of effective approaches for the development of various therapeutic remedies. Thus, the present review comprehensively and critically illustrates the recent aspects on the epidemiology of the virus, the structural and functional features of the viral genome, viral entry and transmission, major mechanisms of pathogenesis and associated virulent factors, current animal models, detection methods and novel strategies for the development of vaccines against MERS-CoV. The review further illustrates the molecular and computational virtual screening platforms which provide insights for the identification of putative drug targets and novel lead molecules toward the development of therapeutic remedies.

Keywords: MERS-CoV, emerging zoonotic virus, mechanisms of pathogenesis, animal models, probable drug targets, vaccine development

\section{INTRODUCTION}

The coronaviruses such as $\mathrm{HCoV}-229 \mathrm{E}, \mathrm{HCoV}-\mathrm{NL} 63$ ( $\alpha$-coronavirus) and $\mathrm{HCoV}-\mathrm{OC} 43$ and HKU1 ( $\beta$-coronavirus) circulated in the human population and caused mild respiratory infections (Hamre and Procknow, 1966; Fouchier et al., 2004; van der Hoek et al., 2004; Woo et al., 2005). Over the last two decades, there have been two zoonotic emergence of coronaviruses into the human population, both linked with Severe Acute Respiratory Syndrome Coronavirus (SARS-CoV) 
(Drosten et al., 2003; Kuiken et al., 2003) and Middle East Respiratory Syndrome Coronavirus (MERS-CoV) (Zaki et al., 2012; Chafekar and Fielding, 2018).

Middle East Respiratory Syndrome Coronavirus belonged to $\beta$-coronavirus, clade-c (van Boheemen et al., 2012; de Groot et al., 2013) and was initially known as Human Coronavirus Erasmus Medical Center/2012. or HCoV-EMC/2012 (Chan et al., 2012). MERS-CoV infections resulted high mortality rate in human, and till date, very limited therapeutic intervention or vaccine are available for the treatment of infections caused by the virus (Mustafa et al., 2017; Hui et al., 2018).

Middle East Respiratory Syndrome Coronavirus found in various natural hosts such as the dromedary calves (Camelus dromedarius), bats (Vespertilio superans and Neoromicia capensis), and European hedgehog (Erinaceus europaeus) (Zhang et al., 2016; Lau et al., 2017). The replication of the virus has observed in various other animals such as rabbit, goat, civet, pig, camelid, and horse (Muller et al., 2012; Chan et al., 2013a; Al-Tawfiq et al., 2014; Eckerle et al., 2014; Meyer et al., 2015). The prevalence MERS-CoV was recently reported in non-camelid domestic mammals such as sheep, goat, donkey, and cow that were in contact with camels (Kandeil et al., 2019). The origin of human MERS-CoV is considered to be from the bats. Several coronaviruses were isolated and found that which were genetically similar to human MERS-CoV. Phylogenetic analysis of MERS-CoV showed that a close relationship to Pipistrellus bat coronavirus HKU5 and Tylonycteris bat coronavirus HKU4 (Selinger et al., 2014). Studies have suggested that there were few evidences where the virus showed camel origin (Zhang et al., 2016). Studies revealed that the sero-prevalence of the virus was greater among the people those who were exhibited direct and indirect contact with dromedary camels when compared to those who were exhibited with the general population (Watson et al., 2014; Zhou et al., 2015; Conzade et al., 2018). Recent study revealed that the prevalence of MERS-CoV infection in camel workers was found to be very high in Saudi Arabia (Alshukairi et al., 2018). Thus, this review provide the recent perspectives on the epidemiology and genome composition of MERS-CoV with a special emphasis on the viral entry, clinical manifestations, mechanism of pathogenesis, animal models, detection, and development of vaccines with an insight on various computational biology perspectives.

\section{EPIDEMIOLOGY}

The first case of MERS-CoV infection was reported in Saudi Arabia in 2012 (Zaki et al., 2012). From the period of its emergence, the virus has infected and propagated across more than 20 countries, contributing to a wide number of laboratory-confirmed cases. In 2015, the MERS-CoV outbreak in South Korea involved 186 cases which included 38 fatalities. A total of $83 \%$ cases of transmission were due to five super spreaders, and $44 \%$ of 186 cases were in the patients those who were experienced nosocomial transmission at 16 hospitals. The epidemic lasted for 2 months and the government authorities quarantined 16,993 persons for 14 days to manage the outbreak.
This outbreak provides an exclusive opportunity to seal the gap in our awareness of MERS-CoV infection (Oh et al., 2018). Recent statistics suggested that as of 31 December 2018 , the total of 2,279 laboratory-confirmed cases of MERS$\mathrm{CoV}$ with 806 associated deaths (case fatality rate: 35.4\%) were reported in 27 countries [Harcourt et al., 2018; World Health Organization (WHO), 2018a]. Among various cases, 1901 confirmed cases with 732 related deaths (fatality rate 38.5\%) were reported from Saudi Arabia [Harcourt et al., 2018; World Health Organization (WHO), 2018a].

In a comprehensive report by WHO, 1841 laboratory cases were confirmed between 2012 and 2016 in which $80 \%$ of them were reported from Kingdom of Saudi Arabia. The remaining cases were reported from 27 countries in Middle East, Asia, North Africa, United States of America, and Europe [World Health Organization (WHO), 2016a]. A total of 13 cases were reported between October to November 2017, amongst which 12 cases were reported in male and only one case was reported in female. Most of the infected individuals were hospitalized due to the contact with camels and consumption of camel milk with the virus [World Health Organization (WHO), 2017a]. Additionally, two laboratory cases were also reported in which the patients belonged to the countries such as Malaysia and United Arab Emirates [World Health Organization (WHO), 2018a]. The laboratory confirmed cases and deaths reported in several countries from the year 2012 to 2018 are shown in Table 1.

\section{THE GENOME OF MERS-CoV}

In the early years of 2000, coronaviruses were not acquired great importance in research and development. With the emergence of SARS in the year 2002 and MERS in 2012, the interest of many researchers was stimulated toward coronavirus (Perlman, 2015).

The morphology of coronavirus includes spherical or pleomorphic shapes with a diameter of 80-120 nm (Masters, 2006). The genome of the coronavirus consists of 6 and 7 open reading frames (ORFs). The ORF $1 \mathrm{a}$ and $1 \mathrm{~b}$ encompass twothird of the viral genome which encodes the non-structural poly-proteins and the other four ORFs on the downstream side encode for the structural proteins such as envelope protein (E), Spike protein (S), nucleocapsid protein $(\mathrm{N})$, and membrane protein $(\mathrm{M})$. In some coronaviruses, hemagglutininesterase (HE) gene is present in the region between ORF $1 \mathrm{~b}$ and S (Marra et al., 2003; Rota et al., 2003; Snijder et al., 2003). These structural proteins are folded and entered in to the endoplasmic reticulum (ER) and transported to the ERGolgi transitional slot (Masters, 2006). During the replication of coronavirus, substantial amounts of structural proteins are synthesized in order to assemble the progeny virions (Fung and Liu, 2014). They occupy the RNA genome which encodes structural proteins such as $\mathrm{S}$ protein, $\mathrm{M}$ protein, and $\mathrm{N}$ protein (Snijder et al., 2003).

The genome size of the first imported MERS-CoV strain was identified to be 30,114 nucleotide (nt) long, including the $3^{\prime}$ and $5^{\prime}$ UTRs. This strain showed the genome structural ornaisation of typical betacoronavirus such as a $5^{\prime}$-untranslated 
TABLE 1 | Laboratory confirmed cases of MERS-CoV infections and deaths reported in several countries from the year 2012 to 2018.

\begin{tabular}{|c|c|c|c|c|}
\hline Year & Region & MERS-CoV infections & $\begin{array}{l}\text { Deaths due to MERS-CoV } \\
\text { infections }\end{array}$ & Reference \\
\hline 2012 & Saudi Arabia, Qatar, and Jordan & 9 & 3 & World Health Organization, 2012 \\
\hline 2013 & $\begin{array}{l}\text { Saudi Arabia, United Kingdom, France, Tunisia, } \\
\text { and Italy }\end{array}$ & 167 & 71 & World Health Organization (WHO), 2013a \\
\hline 2014 & $\begin{array}{l}\text { Saudi Arabia, United Arab Emirates, Jordan, } \\
\text { Iran, and Egypt }\end{array}$ & 765 & 273 & World Health Organization, 2014 \\
\hline 2015 & $\begin{array}{l}\text { Saudi Arabia, Republic of Korea, Jordan, } \\
\text { Kuwait, The Philippines, Thailand, United Arab } \\
\text { Emirates, Oman, Qatar, China, and Iran }\end{array}$ & 680 & 237 & World Health Organization (WHO), 2015a,b \\
\hline 2016 & $\begin{array}{l}\text { Saudi Arabia, United Arab Emirates, Qatar, } \\
\text { Lebanon, and Oman }\end{array}$ & 243 & 75 & World Health Organization (WHO), 2016b \\
\hline 2017 & $\begin{array}{l}\text { Saudi Arabia, United Arab Emirates, Qatar, } \\
\text { Lebanon, and Oman }\end{array}$ & 258 & 81 & World Health Organization (WHO), 2017b \\
\hline 2018 & $\begin{array}{l}\text { Saudi Arabia and Malaysia, United Arab } \\
\text { Emirates }\end{array}$ & 96 & 41 & World Health Organization (WHO), 2018a \\
\hline
\end{tabular}

region (UTR) (nt 1 to 272), replicase complex ORF1ab (nt 273 to 21508), S gene (nt 21450 to 25511), ORF3 (nt 25526 to 25837), ORF4a (nt 25846 to 26175), ORF4b (nt 26087 to 26827), ORF5 (nt26834 to 27508), E gene (nt 27584 to 27832), $\mathrm{M}$ gene (nt 27847 to 28506), $\mathrm{N}$ gene (nt 28560 to 29801), ORF8b gene (nt 28756 to 29094), and 3'UTR (nt 29094 to 30114). The two main poly-proteins such as pplab and ppla are cleaved into 15/16 non-structural proteins (nsp) by 3C-like protease (3CLpro) and papain-like protease (PLpro). These proteases are cleaved from $p p 1 a b$ along with other ORFs encoding nsp which are essential for activating RNA dependent RNA polymerase, helicase, exo-ribonuclease, endo-ribonuclease, and methyltransferase. These nsp were identified to be nsp12, nsp13, nsp14, nsp15, and nsp16. The nsp14 is necessary for proofreading the ubiquitous mutation of RNA virus (Ziebuhr et al., 2000; Snijder et al., 2003; Gorbalenya et al., 2006; Smith et al., 2013; Raj et al., 2014; Durai et al., 2015). Studies revealed that the accessory ORF proteins play an important role in MERS-CoV infection and pathogenesis (Menachery et al., 2017). This study showed that the absence of major accessory ORFs such as deletion of ORF3, $-4 a,-4 b$, and -5 (dORF3-5) played major role in the viral replication and pathogenesis. Further, the attenuation of the mutant dORF3-5 was found to be responsible for the dysregulated host responses such as augmented interferon (IFN) pathway activation, disrupted cell processes, and robust inflammation. Thus, the disruption of accessory ORFs probably provide platform to the attenuation of future emergent strains of MERS-CoV accessory ORF mutants. The accessory ORF functions can be targeted for both therapeutic and vaccine treatments in response to MERS-CoV and related group 2C corona viruses (Menachery et al., 2017). The graphical representation of the genome organization of MERS-CoV is illustrated in Figure 1. Coronaviruses have demonstrated the establishment of double membrane vesicles (DMVs) in the infected cells. Based on immune-histochemistry and electron microscopic studies, the coronavirus replicase proteins are colocalized with the DMVs and are assumed to be the site of replication/transcription complex (Fung and Liu, 2014).
An interesting fact of coronaviruses is that they display recombination, high rates of mutation, and propensity to cross species. One such event was reported during the 2002-2003 epidemic, where the transmission of SARS-CoV has occurred from Chinese horseshoe bats to human populations (Perlman and Netland, 2009). MERS-CoV has the capability to adjust new environments and acquire various virulence factors and enhance their ability to transfer these factors from humanto-human due to continues outbreak (Zumla et al., 2015). The phylogenetic analysis revealed that all human and camel MERS-CoVs were identified to be homologous to each other. Additionally, the hedgehog and bat MERS-CoVs demonstrated para-phyletic group to human and camel MERS-CoV clade (Zhang et al., 2016).

Kim (2016) reported that the occurrence of a mutant strain of MERS-CoV toward the human CD26 receptor during the South Korean outbreak. Furthermore, they isolated 13 new viral genomes in which, 12 possessed point mutation in the receptorbinding domain (RBD) of S protein (Kim, 2016). The S protein is suggested to be essential for the host tropism through its interaction with the host CD26 receptor (van Doremalen et al., 2014; Wang et al., 2014).

\section{PATHOGENESIS}

\section{Viral Entry}

The entry of MERS-CoV to the host is facilitated by its typeI transmembrane glycoprotein known as S protein (Xia et al., 2014). The RBD of MERS-CoV consists of S1 subunit which ranged from 367 to 606 amino acids and can be grouped into an external sub domain and core domain as shown in Figures 1C,D. The receptor-binding motif, V484 - L567 of RBD is situated at the external sub domain and the core sub domain consists of anti-parallel $\beta$-sheet (five-stranded) and six helices in the center. The two small $\beta$-strands make a globular fold. The core domain structure is balanced by three disulfide linkages. The MERS$\mathrm{CoV}$ RBD external sub domain contains a $\beta$-sheet along with 


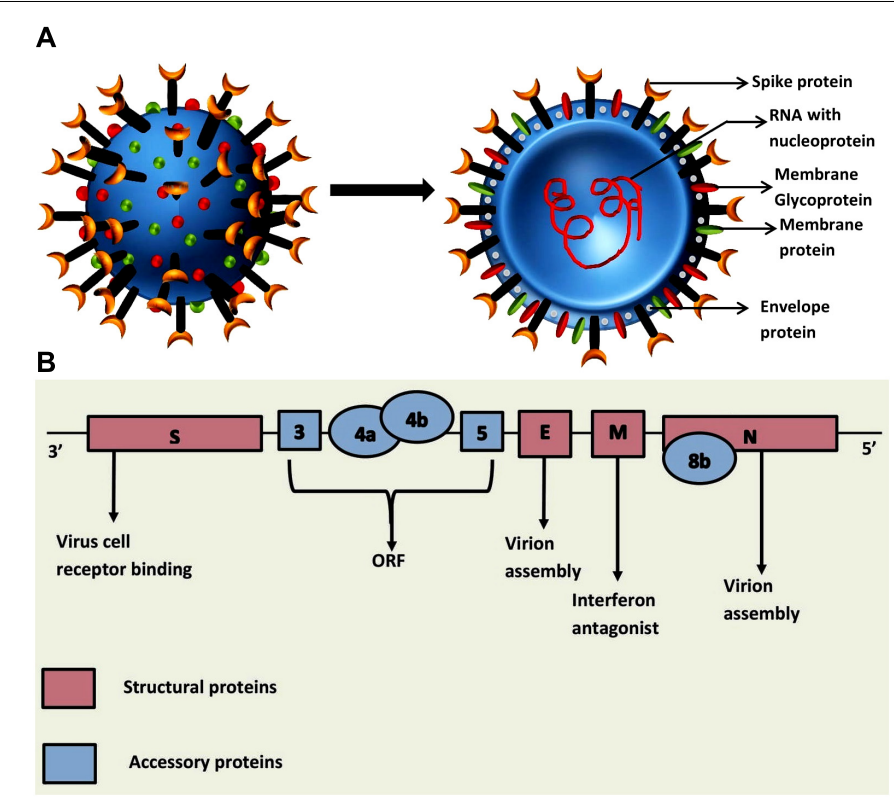

\section{C}

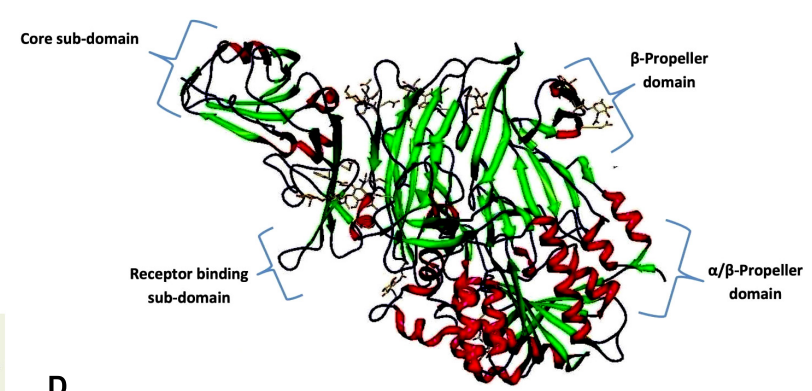

FIGURE 1 | (A) Graphical representation of the structure of the MERS-CoV. The schematic representation shows that the structure of Middle East Respiratory Syndrome Coronavirus, which contains the RNA enclosed in the nucleocapsid within the envelope that is embedded with spike proteins, glycoproteins and membrane proteins (van den Brand et al., 2015). (B) Genome organization of MERS CoV. The genomic organization of MERS-CoV displays the viral genes S, 3, 4a, 4b, 5, E, M, 8b, and N. The genome encodes for five unique accessory proteins such as 3, 4a, 4b, 5 and $8 \mathrm{~b}$ and four major structural proteins which are illustrated in the genome scheme (Gao et al., 2016). (C) Experimental structure of MERS-CoV complexes with human DPP4 (PDB ID: 4L72). DPP4 is an extracellular RBD domain, which comprises of both $\mathrm{N}$ - and $\mathrm{C}$-terminal. The $\mathrm{N}$-terminal is the $\beta$-propeller domain and C-terminal is the $\alpha / \beta$ hydrolase domain (Wang et al., 2013). (D) Genome organization of receptor binding domain (RBD) that illustrates the S1 and S2 sub-domains (Zhang et al., 2015).

one small and three large strands which are organized in antiparallel manner. The RBD core is attached to this region by special intervening loops and it binds to the core sub-domain by a clamp at the lower and upper regions. Most of the connecting loops and two small $3_{10}$ helices are located in the inner region of the sheet. The fourth disulfide linkage is stabilized among the residues starting from C503 to C526 and $\beta 6$-strand linked with $\eta 3$-helix. Three helices (HR1) at the center and three chains (HR2) near to the core promote the release of the viral particle into the cytoplasm and promote the progression of the infection (Durai et al., 2015).

Middle East Respiratory Syndrome Coronavirus can also enter the cell through an auxiliary pathway on the cell surface via transmembrane proteases. The binding of MERS-CoV into host cell and replication of the virus is shown in Figure 2. The host protease cleaves coronavirus S protein into two functional domains distinctive to each other at the $\mathrm{N}$-terminal region (denoted as the S1 subunit) which comprised of RBD, and C-terminal portion (S2 subunit) comprised of a fusion peptide, two heptad repeats (HR2 and HR1) and the transmembrane (TM) domain (Weiss and Navas-Martin, 2005). The membrane fusion is conciliated by main conformational rearrangement which exposed the fusion peptide resulting in the development of six-helix bundle (6HB). The core of $6 \mathrm{HB}$ consists of a triplestranded coiled like structure constructed by HR1s of the three spike subunits forming trimers; the HR2 elements are found to be packed within the grooves of the coiled coil in an anti-parallel direction. Owing to their central role in membrane fusion, it was reported that various antiviral peptides interfere the formation 6HB (Forni et al., 2015).

\section{Transmission and Clinical Presentation}

The clinical presentation of MERS-CoV compasses from severe respiratory diseases to subclinical infections (Drosten et al., 2013; Hui et al., 2018). Infected patients often indicate the presence of hemoptysis, sore throat, fever, cough, shortness of breath, and other gastrointestinal symptoms such as diarrhea and vomiting (Albarrak et al., 2012; Assiri et al., 2013a,b; Guery et al., 2013; Health Protection Agency, 2013; Omrani et al., 2013). A low range of lower pulmonary infiltrate associated with viral pneumonia was observed in the radiograph of patients infected with MERS-CoV (Memish et al., 2013a; Wang, 2014). It was observed that greater than $60 \%$ of the initially reported cases of MERS-CoV infection, the patients experienced severe disease which demanded intensive care treatments like extracorporeal membrane oxygenation and mechanical ventilation. Hematological aberrations delineated for the clinical cases of neutrophilia (8\%), lymphopenia (34\%), thrombocytopenia (36\%), and lymphocytosis (11\%). While the conditions of kidney failure necessitate renal replacement therapy for a considerable number of MERS-CoV cases, several studies detected MERS-CoV antigens and particles in the renal tissues in vivo, which is the direct indication of the virus replication in renal tissues and long term acute infection (Yeung et al., 2016; Alsaad et al., 2018). 


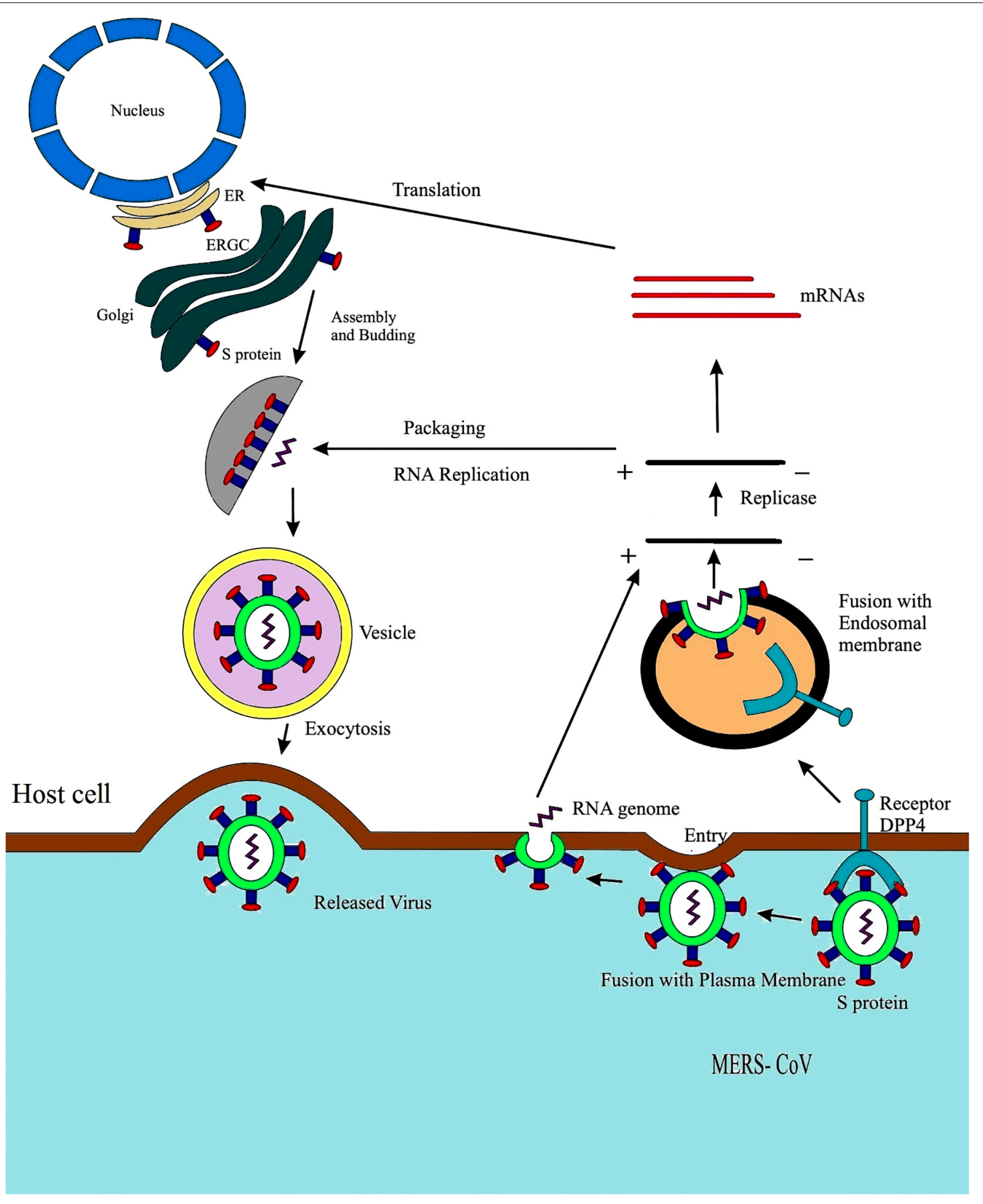

FIGURE 2 | Life cycle of MERS-CoV displaying fusion with plasma membrane. The fusion of $S$ protein to the plasma membrane of host cell, formation of a double membrane vesicle in the host cell, eventually releasing the RNA enclosed in the nucleocapsid followed by genome transcription. The viral RNA undergoes replication and transcription followed by the 4, 5, and 6 RNA synthesis and translation; the endoplasmic reticulum aids the assembly and packaging of virus particle forming a complete double membrane vesicle and lastly through exocytosis and MERS-CoV is released out of the host cell (Du et al., 2009). 
The first evidence of human-to-human transmission of MERS-CoV was reported in few cases in United Kingdom, when an adult male traveled to Saudi Arabia and transferred the infectious virus to two of his family members (Perlman and Netland, 2009). It was suggested that MERS-CoV infections were due to the introduction of the virus in humans and the close contact with camels was one of risk factors for the transmission of MERS as reported by World Health Organization [World Health Organization (WHO), 2016b].

The transmission of MERS-CoV is determined as spasmodic, often healthcare associated, intra-familial, and required prolonged and close contact (Memish et al., 2013a,b, 2014a,b; Puzelli et al., 2013; Drosten et al., 2014). In a domestic study conducted with MERS-CoV infected patients, 14 out of 280 contacts of 26 positively indexed patients (antibody positive or RNA) suggested that the frequency of the transmission even during outbreaks was approximately 3\% (Drosten et al., 2014). Several studies suggested that the virus was not self-sustained, as during local epidemic of MERS-CoV, which has not been readily transmitted to more than one human and has been reported in majority of human related cases (Bauch and Oraby, 2013; Breban et al., 2013; Cauchemez et al., 2014; Chowell and Nishiura, 2014). The mode of transmission of the virus is illustrated in Figure 3.
The serological analysis and extensive investigation of those potentially exposed to the patients suggested that there were no secondary infections [World Health Organization, 2013b]. As a minimum of 18 cases of asymptomatic MERS-CoV infections were reported in health care personals, the function of these subclinical cases in the transfer of infection was found to be uncertain (de Sousa et al., 2014).

\section{Molecular Mechanism of the Pathogenesis}

While there were intensive studies on coronavirus research over the past 5 years, limited reports are available on the pathogenesis of MERS-CoV. Recent post-mortem histopathological studies revealed that the localization of viral particles in the pulmonary and extra pulmonary tissue of a 33-year-old male patient of $\mathrm{T}$ cell lymphoma, who acquired MERS-CoV infection (Ng et al., 2016; Alsaad et al., 2018). The histopathological analysis of the biopsies were collected from lung, brain, liver, heart, kidney, and skeletal muscle demonstrated that there were pulmonary diffuse alveolar damage, necrotizing pneumonia, acute kidney injury, portal and lobular hepatitis and myositis with muscle atrophic changes. Further, the viral particles were found to be localized in the pulmonary macrophages, pneumocytes, renal proximal

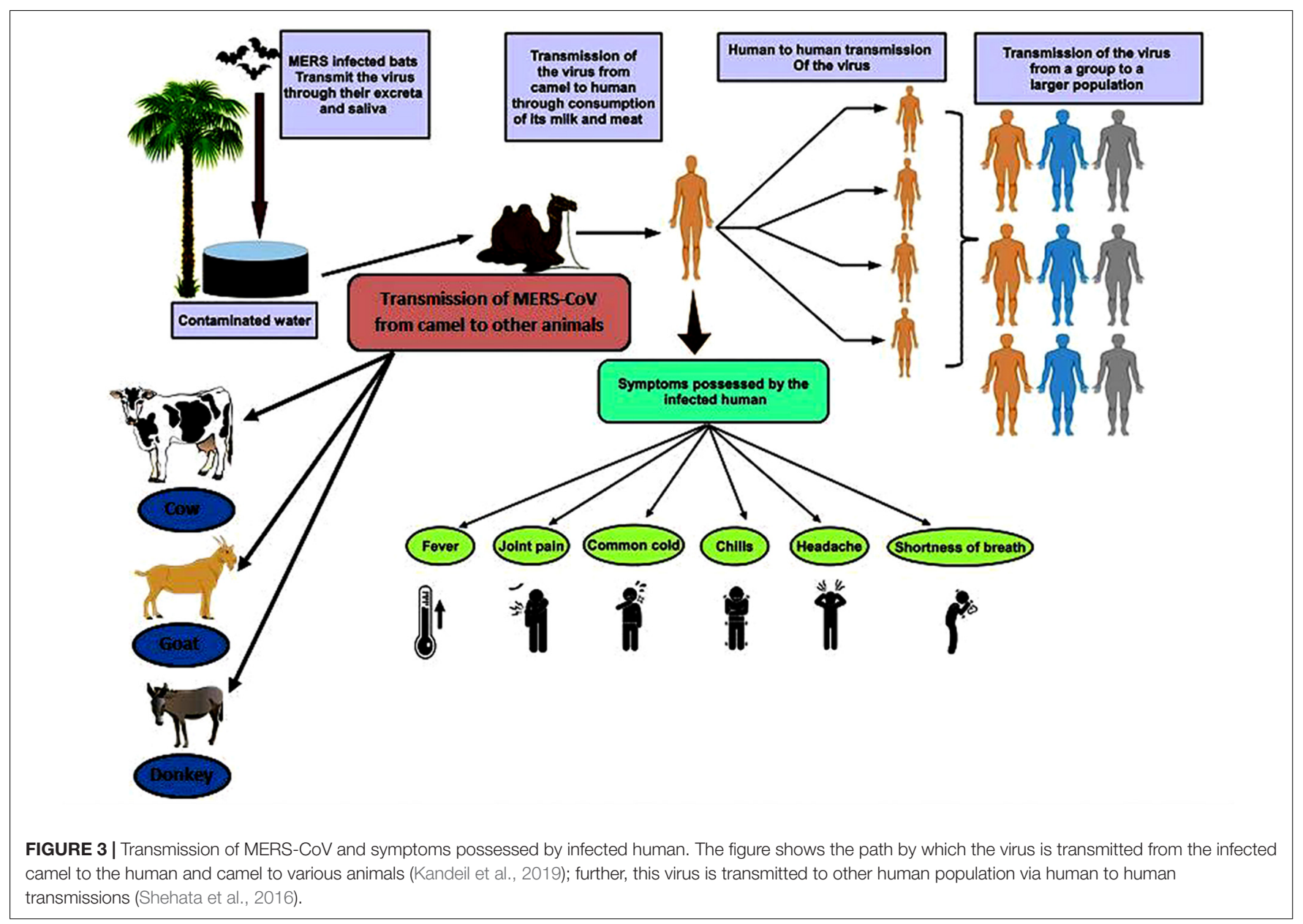


tubular epithelial cells and macrophages infiltrating the skeletal muscles (Alsaad et al., 2018).

Studies suggested that the pathogenesis of MERS-CoV in human and animals are mainly due to three mechanisms such as DPP4 (dipeptidyl peptidase-4) mediated mechanism, papain like protease PLpro mediated mechanism and accessory proteins like $\mathrm{p} 4 \mathrm{a}$ and membrane $\mathrm{M}$ protein mediated mechanism. Hence, these proteins are probably considered as one of the potential therapeutic targets for MERS-CoV infections (Durai et al., 2015). The molecular mechanisms exhibited by various modes of pathogenesis are illustrated in Figure 4.

\section{DPP4 MEDIATED MECHANISM}

DPP4 is a type-II transmembrane glycoprotein consists of approximately 766 amino acids and function as major receptor for MERS-CoV. The three dimensional structural analysis revealed that this receptor has $\alpha / \beta$-hydrolase domain and a $\beta$-propeller domain with eight blades that helped in the binding of receptor binding domain in MERS-CoV (Raj et al., 2014). The crystal structure of DPP4 is illustrated in Figure 1C. A DPP4 binding protein, adenosine deaminase, is considered as one of the major inhibitors of the S protein of MERS-CoV (Drosten, 2013).

A number of cell lines such as human-derived HFL, Calu-3, Caco-2, Huh-7, HEK, His-1 cell lines, CD8+, and CD4+ that are susceptible to MERS-CoV were reported (Chan et al., 2013b; Shirato et al., 2013; Chu et al., 2016). Two S protein ecto-domains can be divided into fusion-catalyzing domains (FD) and RBD. The S RBDs bind to DPP4 after which the FDs are exposed through unfolding. Further, the cellular and viral membranes were joined together by refolding (Raj et al., 2013). The unfolding FD required the cleavage of S protein by host proteases. Out of various proteolytic cleavage sites between the FD and $\mathrm{RBD}$, the cleavage at S1/S2 site is essential for the infection of Calu3 cells by MERS-CoV (Park et al., 2016).

It has been revealed that upon infection, monocyte chemo attractant protein-1 and IFN- $\gamma$-inducible protein-10 were induced and suppressed the proliferation of human myeloid progenitor cells (Zhou et al., 2014). MERS-CoV can infect T-cells from human lymphoid organs and causes the peripheral blood inducing apoptosis by intrinsic and extrinsic pathways

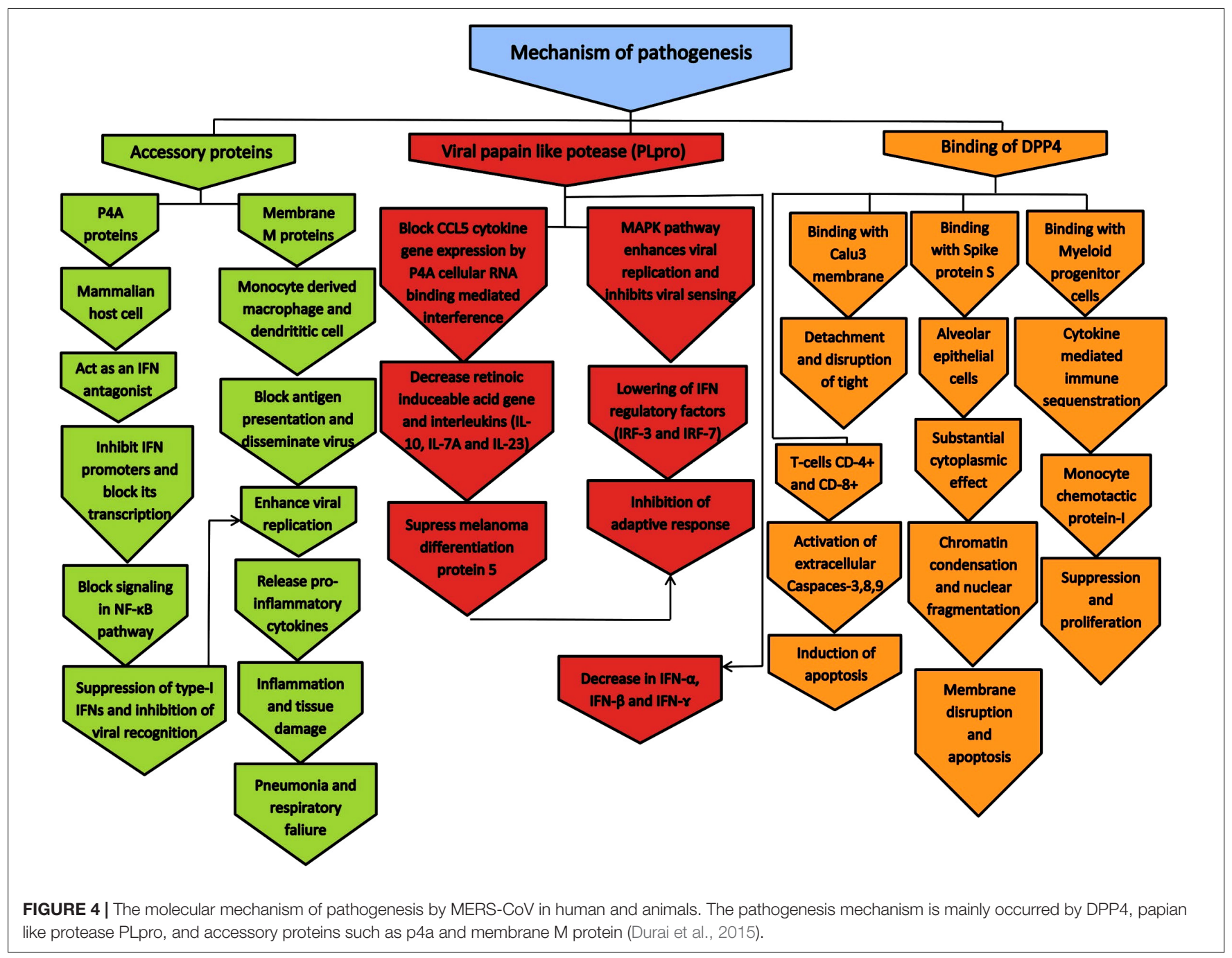


(Chu et al., 2016). A study conducted by Al-Qahtani et al. (2017) suggested that the inhibition of DPP4 mitigated the induction of PPAR $\gamma$ (the transcriptional repressor) and IRAK$M$ (negative regulator of TLR signaling) which indicated that the immunosuppressive action of S glycoprotein regulated by DPP4.

\section{PAPAIN LIKE PROTEASE PLpro MEDIATED MECHANISM}

Upon entry into the cells, two ORFs at the $5^{\prime}$-end of the viral genome are translated into two poly-proteins. They are processed by two viral proteases, PLpro and 3C-like proteinase (3CLpro) and form 16 nonstructural proteins which are necessary for the membrane-associated replication complex. PLpro is located in nonstructural protein 3. PLpro was found to be multifunctional enzymes with deISGylating (removal of ISG15 conjugates from host cell factors) and deubiquitinating (cleavage of ubiquitin from host cell factors) properties in addition to protease activity in many coronaviruses (Clasman et al., 2017). This resulted in the host antiviral immune response being antagonized and promoting the viral replication. PLpro can inhibit the mitochondrial anti-viral signaling protein induced IFN- $\beta$ reporter activity and reduce TNF- $\alpha$ induced NF- $\kappa$ B reporter activity. Hence, MERS-CoV PLpro is considered to be important antiviral target (Mielech et al., 2014; Harrigan et al., 2018).

The coronavirus genome is encoded by two ubiquitin-like domains (Ubl1 and Ubl2), out of which Ubl2 is considered to be an important component which influences the PLpro activity. Clasman et al. (2017) reported that PLpro has not showed the deISGylating, de-ubiquitinating or protease activities in the absence of Ubl2 domain. There were no variations in the process of inhibition, substrate specificity, catalytic efficiency and thermal stability (Clasman et al., 2017).

\section{ACCESSORY PROTEINS MEDIATED MECHANISM}

The viral genome is recognized by melanoma differentiationassociated protein-5 (MDA5), retinoic acid inducible gene-1 (RIG-1) and endosomal toll-like receptor 3 (TLR3) as pathogenassociated molecular patterns. This recognition resulted in the formation of type-1 interferon (IFN1). As an evasion mechanism, virus synthesize proteins that hinder the production IFN1 in the pathway (Zinzula and Tramontano, 2013).

In the absence of MDA5 and RIG-1, MERS-CoV used the protein such as $4 \mathrm{a}$ (p4a) which contain RNA-binding motif for binding (Rabouw et al., 2016). By a direct binding, this motif masks the dsRNA of MERS-CoV. The p4a possesses $\alpha \beta \beta \beta \alpha$ fold with the $\beta 1-\beta 2$ loop and $\alpha 1$ helix which bind to the minor groove of dsRNA. The mutational studies revealed that p4a-dsRNA complex stabilized by the amino acids such as K27, W45, K63, and K67 (Batool et al., 2017). In a study carried out by Canton et al. (2018) suggested that, NF- $\mathrm{B}$ remained in the cytoplasm of MERS-CoV infected cells while $4 \mathrm{~b}$ was found to be attached with the nucleus. In the absence of $4 \mathrm{~b}$, expression of pro-inflammatory cytokines was observed as NF- $\mathrm{B}$ translocated to the nucleus. This was also observed in the case of $4 \mathrm{~b}$ mutants that devoid of nuclear localization signal, indicating that nuclear localization signal mediated process of $4 \mathrm{~b}$ is essential for NF- $\kappa \mathrm{B}$ expression (Canton et al., 2018).

As a component of the viral envelope, $M$ protein is involved in various functions such as viral assembly along with other proteins such as E, S, N. The M, E, and S proteins interact with $\mathrm{N}$ protein in the ER-Golgi complex. This interaction hinders the fusion of viral and cellular membranes (Mustafa et al., 2018). It was observed that the expression of $M$ protein in MERS$\mathrm{CoV}$ might suppressed the type-I IFN expression in response to poly (I: C) induction or Sendai virus infection. This reaction was detected to be specific for the activation of IFN regulatory factor 3 (IRF3), however, not activated the nuclear factor- $\kappa \mathrm{B}$. The interaction of MERS-CoV M protein with TRAF3 and the association of disrupted TRAF3-TBK1 lead to reduced activation of IRF3 (Lui et al., 2016).

\section{HOST IMMUNE RESPONSE}

Middle East Respiratory Syndrome Coronavirus can readily infect human respiratory epithelial cells, macrophages, T-cells, dendritic cells and can influence the production and induction of pro-inflammatory cytokines and chemokines (Zhou et al., 2015). Studies on ex vivo human lung tissue and respiratory epithelial cell lines showed that the induction of antiviral interferons followed by MERS-CoV infection by stimulated epithelial cells was found to be limited. A study by Menachery et al. (2014) described that the cells infected with MERS-CoV demonstrated distinctly altered chromatin structures such as repressive histone markers, that could limit the transcription factors from binding to the promoter regions of interferon-stimulated gene. The changes in DNA methylation found to be one of the reasons for down regulation of IFN- $\gamma$-associated antigen-presenting gene after the infection (Menachery et al., 2018). MERS-CoV proteins such as $4 \mathrm{a}, 4 \mathrm{~b}, \mathrm{M}$, and PLpro were found to be suppressed the induction of interferons (Yang et al., 2013; Mielech et al., 2014; Canton et al., 2018). Further, the induction of pro-inflammatory cytokine response in these cells was found to be limited. A delayed induction of pro-inflammatory cytokines/chemokines such as IL6 , IL-8, and IL-1 $\beta$ were observed upon the viral infection (Lau et al., 2013; Canton et al., 2018).

Middle East Respiratory Syndrome Coronavirus could infect and replicate in human monocyte-derived macrophages and immature monocyte-derived dendritic cells, while it failed to perform similar functions in mature monocyte-derived dendritic cells. This indicate that the maturation restrict the viral replication. Immature dendritic cells were unable to stimulate T-cell even after the antigen uptake, delaying the activation of T-cells and permitting further viral replication (Cong et al., 2018). The infection of human macrophages induced the expression of pro-inflammatory cytokines/chemokines such as MCP-1/CCL-2, IFN- $\alpha 2$, IFN- $\gamma$, MIP- $1 \alpha / C C L-3$, IP10/CXCL-10, RANTES/CCL-5, IL-8, TNF- $\alpha$, IL-12p40, and IL-6 
(Zhou et al., 2015; Cong et al., 2018). The infected dendritic cells induced the expression of IL-12, RANTES/CCL-5, IP-10/CXCL10 and IFN- $\gamma$, however, showed low expression of IFN- $\alpha$ and no expression of IFN- $\beta$ (Zhou et al., 2015).

T-cells can be directed to the infection site by type-I IFN stimulated secretion of IL-10 and CXCL10. Due to their uncontrolled and strong expression, the expression of IFN$\gamma$ and IL-12 were inhibited and restricted the activation of T-helper cells. With the added effect of down-regulated antigenpresentation pathways, the activation of $\mathrm{T}$ cells is inhibited. Hence, the sequestered T cells failed to target the virus (Ying et al., 2016). Previous studies revealed that when the serum samples and bronchoalveolar lavage were analyzed from two patients, it was observed that the patients with low level secretion of IFN- $\alpha$ were failed to survive and the patients displayed high level secretion of type-I IFN were survived (Faure et al., 2014).

\section{ANIMAL MODELS}

The animal models are one of the vital components for translation of the findings from drug discovery process from bench to bedside. These animal models are indispensable for the deeper understanding of any diseases and safe and protective vaccine development process (Lorenzen et al., 2015). The main criteria for the validation of animal models in preclinical studies are face validity, predictive validity and target validity. The face validity means that the proper similarity between the animal model and the human disease in terms of the biology and symptoms of the disease. However, assessing face validity is a tedious task due to the lack of understanding on the core biology of the disease symptoms. Predictive validity means the display of clinical interventions which exhibited similar effect in the animal models. This is also very difficult to achieve due to the incomplete correlation between animal models, the mechanism of human diseases and the incapability of standard drugs to active in many animal models. Target validity is another essential component for the validation of animal models in which the target under study must have an analogous function in the disease model as in the clinical condition (Denayer et al., 2014).

An ideal animal model is the one where an immunocompetent animal, on receiving the challenge virus at a realistic dose through a suitable inoculation route, is able to replicate the characteristics of a human disease as closely as possible (Doremalen and Munster, 2015). Ferrets, hamsters, mice and other small laboratory animals are not ideal animal models for MERS-CoV owing to the variations in DPP4 receptor. The rhesus macaque and the common marmoset are the first non-human primate species (NPS) to be used as the animal models for MERS-CoV. Glycosylation of mouse DPP4 (mDPP4) prevents its binding to $\mathrm{S}$ protein of MERS-CoV. Hence, transgenic hDPP4 (human DPP4) mice were developed as animal model (Peck et al., 2015). The major advantages and limitations of MERS-CoV animal models are listed in Table 2.

\section{Mice}

Studies suggested that the glycosylation of certain amino acids prevented the binding of mouse DPP4 (mDPP4) to S protein of MERS-CoV (Doremalen and Munster, 2015). The first transgenic MERS-CoV mouse model was established by Agrawal et al. (2015). The mice expressed hDPP4 and developed severe respiratory MERS-CoV infections. The transgenic mice infected with an intra-nasal dose of $10^{6}$ TCID50 of MERS-CoV developed pneumonia, weight loss, acute pulmonary viral infection, ruffled fur, squinting, and death within few days (Agrawal et al., 2015). A transgenic mouse model developed by Zhao et al. (2015) showed that limited utility for pathogenic studies due to the systemic dissemination and development of severe neurological diseases. The other lung infection models were lack mortality and weight loss, however, developed lung pathology in response to $50 \%$ TCID $^{50}$ of MERS-CoV (Tao et al., 2015).

Recent studies suggested that the transgenic mice models were developed where the full-length MDPP4 gene replaced by hDPP4 (Coleman et al., 2017). The infection and replication of MERS$\mathrm{CoV}$ was observed in the lungs, however, disseminated slow

TABLE 2 | Advantages and limitations of MERS-CoV experimental animal models.

\begin{tabular}{|c|c|c|c|}
\hline Species & Advantages & Limitations & Reference \\
\hline Rabbit & Readily available and easy to handle & $\begin{array}{l}\text { Animal-to-animal transmission studies are not } \\
\text { available No clinical disease, Low viral titers in } \\
\text { tissues upon infection Develop mild pulmonary } \\
\text { lesions }\end{array}$ & $\begin{array}{l}\text { Haagmans et al., 2015; } \\
\text { Vergara-Alert et al., } 2017\end{array}$ \\
\hline Rhesus macaques & $\begin{array}{l}\text { Human-specific reagents available for immunologic } \\
\text { analysis Immune and respiratory systems similar to } \\
\text { humans; clinical disease similar to humans Useful } \\
\text { for confirming vaccine efficacy testing }\end{array}$ & $\begin{array}{l}\text { Limited availability and expensive Expert } \\
\text { husbandry requirements Animal-to-animal } \\
\text { transmission studies are not available Transient } \\
\text { disease Ethical concerns }\end{array}$ & $\begin{array}{l}\text { Baseler et al., 2016; Yu et al., } \\
2017\end{array}$ \\
\hline Common marmoset & $\begin{array}{l}\text { Model severe, potentially fatal MERS-CoV infection } \\
\text { Some human-specific immunological reagents } \\
\text { cross-react Respiratory and immune systems } \\
\text { similar to humans; clinical disease similar to } \\
\text { humans Useful for confirming antiviral and vaccine } \\
\text { efficacy testing }\end{array}$ & $\begin{array}{l}\text { Limited availability and expensive Expert } \\
\text { husbandry requirements Ethical concerns } \\
\text { Animal-to-animal transmission studies are not } \\
\text { available }\end{array}$ & $\begin{array}{l}\text { Vergara-Alert et al., 2017; Yu } \\
\text { et al., } 2017\end{array}$ \\
\hline hDPP4-transgenic mice & $\begin{array}{l}\text { Model severe, potentially fatal MERS-CoV infection } \\
\text { Easy to handle Reagents available Useful for } \\
\text { screening antivirals and vaccines }\end{array}$ & Global over expression of hDPP4 & $\begin{array}{l}\text { Baseler et al., 2016; Coleman } \\
\text { et al., } 2017\end{array}$ \\
\hline
\end{tabular}


impact to the other organs during the post injection with dose range of 102-105 PFU. The pathology of infected mice showed pneumonia-like symptoms (Coleman et al., 2017).

The CRISPR-Cas9 gene editing tools were used to produce mice susceptible to MERS-CoV infection by modifying their genome sequence (positions 288 and 330) homologous to the sequence of hDPP4. In certain mice model the characteristic symptoms such as pulmonary hemorrhage, low survival, decreased pulmonary function and weight loss were observed. The 288-330+/+MERS-CoV mouse model demonstrated severe respiratory infection as observed in humans (Cockrell et al., 2016).

\section{Rhesus Macaques and Marmosets}

Upon infection with MERS-CoV, rhesus macaques and marmosets were developed moderate respiratory disease which are comparable with mild human MERS-CoV infection. As observed in human cases, they also showed complete blood count abnormalities. Rhesus macaque and marmoset models were found to be suitable for pathogenic studies of mild infections. Both the models can be used for the efficacy testing of prophylactic and therapeutic countermeasures (Baseler et al., 2016).

Yu et al. (2017) reported that when 2-3 old rhesus macaques and common marmosets were intra-tracheally injected with hCoV-EMC, hematoxylin and eosin stained tissues of the infected model demonstrated lesions primarily in the lungs with various degrees of inflammation, hemorrhaging, pulmonary oedema, interstitial pneumonia, eosinophil infiltration and necrosis in bronchial epithelial cells and pneumocytes. The lungs of the infected marmosets demonstrated widespread pulmonary oedema and hemorrhaging. The oedematous alveolar cavities showed fibrinous exudates and neutrophil infiltration. In both the cases, DPP4 was widely expressed in alveolar macrophages and type-I and II pneumocytes were also actively involved. The pathological changes as a result of viral infection were not observed in any other organs of the infected animal (Yu et al., 2017).

\section{Rabbits}

In most cases, MERS-CoV causes severe infection in the lower respiratory tract in humans. Nasal swabs collected from the infected rabbits demonstrated the presence of MERS-CoV. They generally develop respiratory diseases such as asymptomatic and mild human infections as sometimes observed in immunecompetent patients (Haagmans et al., 2015).

Recently, Houser et al. (2017) revealed that the infected New Zealand rabbits were developed asymptomatic pulmonary infections with high levels of viral antigens and RNA. Multiple lung lobes showed peri-vascular inflammation. The antibodies developed by the rabbits lacked neutralizing activity, and as a result the animals were susceptible to re-infection. In fact, enhanced pulmonary inflammation was observed after re-infection. However, re-infection elicited the neutralizing antibodies (Nabs). Hence, it was suggested that upon re-infection, there might be greater risk of severe lung disease in those who do not develop neutralizing antibody response, or those whose neutralizing antibody titers have decreased after the initial infection (Houser et al., 2017). The clinical signs and lesions along with the occurrence of MERS-CoV RNA and antigens observed in MERS-CoV infected animal models are shown in Table 3.

\section{DIAGNOSTIC APPROACHES}

The primary diagnosis of MERS-CoV infection was performed by molecular techniques such as real-time reverse transcriptase PCR (RT-PCR) (Corman et al., 2012a), reverses transcriptionloop-mediated isothermal amplification (RT-RTPA) (Shirato et al., 2014) and reverses transcription-recombinase polymerase amplification (RT-LAMP) (Abd et al., 2013). Numerous serological assays were used to detect MERS-CoV or closely related viruses in seropositive camels; these tests were protein microarrays like indirect enzyme-linked immunosorbent assay (ELISA), recombinant spike immunofluorescent assay, spike pseudoparticle neutralization and microneutralization assay (Buchholz et al., 2013; Perera et al., 2013). However, none of the serological assays showed evidence of the precise occurrence of MERS-CoV in camels (Song et al., 2015). Recent study reported that a rapid and specific assay for the detection of MERS-CoV such as nucleic acid visualization technique which combine the reverse transcription loop-mediated isothermal amplification technique and a vertical flow visualization strip (RT-LAMP-VF) to detect the $\mathrm{N}$ gene of MERS-CoV (Huang et al., 2018). The study suggested that in comparison with the

TABLE 3 | Clinical signs and lesions along with the occurrence of MERS-CoV RNA and antigens as seen in MERS-CoV infected animal models.

\begin{tabular}{|c|c|c|c|c|c|}
\hline Animal model & Clinical signs & Lesions & $\begin{array}{l}\text { Occurrence of } \\
\text { MERS-Cov RNA }\end{array}$ & $\begin{array}{l}\text { Occurrence of } \\
\text { MERS-antigen }\end{array}$ & Reference \\
\hline Rabbit & Asymptotic & Rhinitis with necrosis & $\begin{array}{l}\text { Lung, upper respiratory } \\
\text { tract, lymph nodes }\end{array}$ & $\begin{array}{l}\text { Type I and II } \\
\text { pneumocytes }\end{array}$ & Haagmans et al., 2015 \\
\hline Rhesus Macaques & $\begin{array}{l}\text { Mild to moderate } \\
\text { respiratory disease }\end{array}$ & Interstitial pneumonia & $\begin{array}{l}\text { Lung, lymph nodes, } \\
\text { upper respiratory tract }\end{array}$ & $\begin{array}{l}\text { Type I and II } \\
\text { pneumocytes, alveolar } \\
\text { macrophages }\end{array}$ & $\begin{array}{l}\text { de Wit et al., 2013a,b; } \\
\text { Yao et al., 2014; Yu } \\
\text { et al., } 2017\end{array}$ \\
\hline Common Marmoset & $\begin{array}{l}\text { Mild to severe } \\
\text { respiratory disease }\end{array}$ & $\begin{array}{l}\text { Broncho-interstitial } \\
\text { pneumonia }\end{array}$ & $\begin{array}{l}\text { Lung, blood, lymph } \\
\text { nodes, visceral organs, } \\
\text { upper respiratory tract }\end{array}$ & $\begin{array}{l}\text { Type I pneumocytes, } \\
\text { alveolar macrophages }\end{array}$ & $\begin{array}{l}\text { Falzarano et al., 2014; } \\
\text { Yu et al., } 2017\end{array}$ \\
\hline hDPP4- transgenic mice & $\begin{array}{l}\text { Severe fatal respiratory } \\
\text { disease }\end{array}$ & $\begin{array}{l}\text { Broncho-interstitial } \\
\text { pneumonia }\end{array}$ & $\begin{array}{l}\text { Lung, brain, } \\
\text { visceralorgans }\end{array}$ & $\begin{array}{l}\text { Type I and type II } \\
\text { pneumocytes }\end{array}$ & Agrawal et al., 2015 \\
\hline
\end{tabular}


real-time RT-PCR (rRT-PCR) method recommended by the World Health Organization, the RT-LAMP-VF assay is easy to perform and the rapid detection of MERS-CoV within $35 \mathrm{~min}$ was achieve by this approach (Huang et al., 2018).

An assay was developed based on the detection of $\mathrm{N}$ protein of MERS-CoV (Song et al., 2015). The NP protein preferred as better target than the $S$ protein. In this type of assay, firstly, the antigen binds to gold labeled monoclonal antibodies which lead to the formation of antigen-antibody complex. The complex further passed through nitrocellulose membrane and bind to monoclonal antibody at the test region and formed band which could be conveniently analyzed (Tang, 2014).

Currently, multiple purified monoclonal antibodies are available in clinical and preclinical studies for the development of antimicrobials (Rockx et al., 2010). Studies suggested that two human antibodies (REGN3048 and REGN3051) are known to bind with MERS-CoV RBD and prevent the interaction of cellular receptor DPP4 with S protein and effectively neutralize MERS-CoV infection (Pascal et al., 2015). The antibodies such as REGN3048 and REGN3051 showed no binding with S protein, thus, employed as effective combination for inhibiting MERSCoV (Aderem et al., 2011). REGN3048 and REGN3051 cointeract with MERS-CoV RBD, which suggested that these antibodies bind to discrete epitopes as they bind to regions of MERS-CoV S protein that are conserved during the natural evolution of the virus. These two antibodies were blocked entry of the virus into susceptible cell lines and neutralize the infection (Pascal et al., 2015).

The diagnostically relevant variations in the neutralization activity have not been detected in several isolates of MERS$\mathrm{CoV}$. In order to detect the serological response to a specific type of single MERS-CoV serotype, specific protein based sero-assays are essential to be performed (Muth et al., 2015). The development of potential serological assays demand well delineated human or animal sera and antibodies specific to MERS-CoV (Meyer et al., 2014).

\section{VACCINES AND THERAPEUTICS}

Previous studies revealed that both cellular and humoral responses are required for the complete protection against MERS-CoV infections (Faure et al., 2014; Park et al., 2015; Corman et al., 2016). Nabs and T-cell responses are the main agents in providing protective immunity against coronaviruses. In a study by Zhao et al. (2014) reported that MERS-CoV cleared by mice which lack B-cells while those deficient in T-cells failed to perform similar functions. Further, since virus-specific humoral responses were decreased over time, developing a vaccine which could induce long-lived memory T-cell response considered to be beneficial. However, any vaccine compounds which are able to induce both $\mathrm{T}$ and $\mathrm{B}$-cell responses are required for immune protection (Okba et al., 2017).

\section{Current Vaccine and Antiviral Candidates}

MERS-CoV vaccine candidates are still under development with DNA based, protein based, live attenuated and vectored-virus based vaccines (Arabi et al., 2017). Out of the four structural proteins and sixteen non structural proteins encoded by the viral genome, $\mathrm{S}$ protein showed the highest immunogenicity which induced T-cell responses. In most of the MERS-CoV, Nabs target the $\mathrm{RBD}$ of the $\mathrm{S}$ protein. The variations in amino acid sequences of the $\mathrm{S}$ protein detected amongst MERS-CoV is limited, thus, designing a vaccine against one strain most likely to be protected against all the other circulating strains (Okba et al., 2017). The S1 protein located outside the RBD probably considered as potential drug target to develop therapeutic strategies against MERS-CoV. RBD-specific mAbs are considered to be displayed greater neutralizing activity than those were targeted the S1 or S2 region outside RBD (Du et al., 2013).

DPP4-targeting therapeutic agents are capable of blocking the interaction between MERS-CoV RBD and DPP4, and therefore inhibit MERS-CoV infection. The anti-DPP4 (CD26) antibodies such as 1F7, 2F9, and YS110 prevent the entry of MERS-CoV into susceptible cells, obstructing the virus infection (Ohnuma et al., 2013). Additionally, DPP4-binding protein adenosine deaminase (ADA) competes the binding with MERS-CoV RBD to DPP4, specifically at crucial residues such as Q286 and L294, defining their role as a naturally occurring antagonist (Raj et al., 2014).

Recent studies revealed that the DNA vaccines are the safest vaccines for immune-compromised patients. They possessed comparatively greater amounts of DNA (e.g., 0.5-2 mg) thus requires multiple inoculations to induce potent immune responses in rhesus macaques and mice (Wirblich et al., 2017). Chi et al. (2017) developed a DNA vaccine which encoded the first 725 amino acids of S protein in MERS-CoV which induced the cell mediated and antigen-specific humoral immune responses in mice. Post three immunizations, it was observed that high titers of Nabs (up to 1: 104) were produced without any adjuvant. A prophylactic DNA-plasmid vaccine known as GLS-5300, which encodes for S protein, is the first MERS-CoV vaccine to be considered for the human trials developed by GeneOne Life Inc., which has been enlisted in the on-going list of vaccines by WHO [Rabaan et al., 2017; World Health Organization (WHO), 2018b].

The vaccines that imitate the natural infection, such as recombinant viral vectors or live-attenuated virus present the antigens in natural ways which further stimulate the activation of humoral and cell-mediated immunity to the native protein conformation. As the live attenuated viruses have been the most immunogenic platforms available, they exhibited the capability to present numerous antigens across the viral life cycle in their native conformations (Henderson and Moss, 1999). Agrawal et al. (2016) vaccinated the mice with an inactivated MERS-CoV vaccine and which demonstrated hypersensitivity risk factors in MERS-CoV infection. Although there were extensive research in the last few years, limited anti-MERS-CoV therapeutics have been approved for human use. Originally, conventional IFAs were employed in the human sero-surveys and these relied on the MERS-CoV infected cell cultures. These cell cultures were the primary antigen sources for detecting the presence of human anti-MERS-CoV Nabs, IgM, and IgG in human samples (Corman et al., 2012b). Further, it was reported that human monoclonal 
antibody m336 demonstrated significant neutralizing properties against MERS-CoV in vitro conditions (Houser et al., 2016).

Recent studies revealed that there were few antiviral agents in the developmental stage. It was reported that the antiviral drug chlorpromazine demonstrated strong anti-MERS-CoV potential; however, the high cytotoxicity of the drug limiting the potential window for drug utilization. Similarly, another drug Toremifene showed moderate activity when tested in antigen presenting cells, however, the high cytotoxicity of this drug also narrowing its application as a therapeutic remedy against MERS-CoV (Cong et al., 2018). Further, studies suggested that a nucleoside analog GS-5734 known as Remdesivir, which showed potential antiviral activity against human and zoonotic CoVs in vitro and the drug inhibited MERS-CoV at 50\% effective concentration values (EC50) (Agostini et al., 2018).

\section{NOVEL THERAPEUTIC APPROACHES}

The conserved nature of the $\mathrm{N}$ protein was used to develop vaccines that can induce an adaptive immune response against these proteins. In a study by Zhao et al. (2016) reported that a vaccine candidate induced airway memory CD4+ $\mathrm{T}$ cell response against $\mathrm{N}$-specific epitopes of MERS-CoV. In another study suggested that vaccination with recombinant $\mathrm{N}$-terminal domain (rNTD) triggered greater T-cell response than the mice vaccinated with rRBD. The neutralizing activity was also observed in the sera (Jiaming et al., 2017). Recent study revealed that the combination of fusion inhibitory peptide which targets the protein HR1 domain of MERS-CoV S2 and a neutralizing antibody specific for the $\mathrm{S} 1$ protein $\mathrm{RBD}$ showed synergistic therapeutic activities against MERS-CoV (Wang et al., 2019). Further, the researchers have developed novel neutralizing nanobodies $(\mathrm{Nb})$ which specifically bind to the RBD of MERS$\mathrm{CoV} \mathrm{S}$ protein. The $\mathrm{Nb}$ was found to be interacted with the conserved domain of MERS-CoV RBD with high affinity and blocked binding of RBD to the receptor of MERS-CoV (Zhao et al., 2018).

Some immunodominant epitopes within the protein structure may contribute negatively to the neutralization activity of the vaccine. For example, a short region of $\mathrm{RBD}$ was able to induce higher titer of IgG when compared to other longer regions (Ma et al., 2014). The negative effects of these epitopes can be surmounted by immunofocusing; mapping of the most neutralizing RBD fragment and eliminating unnecessary fragments. This can help in focusing the immune response to important epitopes (Ma et al., 2014). Pallesen et al. (2017) suggested that the structure-based design of S proteins improved their immunogenicity where the high titers of Nabs were observed against MERS-CoV. The major categories of vaccines developed and tested against various animal models are shown in Table 4.

\section{Therapeutic Screening by Computational Biology}

The technological progression is reflected upon a series of genome wide molecular screening platforms and computational biology approaches that provided novel insights to prompt response against emerging viral diseases. The prototype of these approaches included the in vivo animal model, tissue culture model, human challenge model, and vaccine studies. These model systems are anxious by challenges, preferably yielding a spectra of the severity of the diseases like lethal versus sub-lethal in order to increase divergence for downstream data mining and modeling (McDermott et al., 2011; Drosten et al., 2013; Law et al., 2013). A diversity of computational methodologies and network approach were used to detect the regulatory networks of various viral systems by de novo studies (Hou and Zhao, 2013; Mitchell et al., 2013).

Recently, studies have shown that peptides can be utilized as highly potent signal transduction agents for various viral infections. It has been suggested that antimicrobial peptides (AMPs) can be used as potential therapeutic option against MERS-CoV infections (Mustafa et al., 2018). Computational biology approach in combination with virology can be employed to design novel peptide based therapeutics against various strains of MERS-CoV with high efficacy. Recent studies have suggested that repurposing of existing and clinically approved anti-viral peptides can be used as promising lead molecules for the development of novel anti-MERS-CoV agents (Mustafa et al., 2018).

The RBD and S protein based vector vaccines are considered to be one of the efficient targets for designing MERS-CoV vaccine, as it comprised of multiple neutralizing epitopes which offer higher potential to prompt Nabs against the virus (Shi et al., 2015). The vast developments in computational biology have led to the new line of immunoinformatics databases and tools, which are other operative ways for vaccine development (Terry et al., 2015).

TABLE 4 | Categories of vaccine developed against MERS-CoV, their potential candidate, and their target long with their immunological response and efficacy.

\begin{tabular}{|c|c|c|c|c|c|c|}
\hline Vaccine categories & Vaccine candidate & Target antigen & Animal model & Immunological response & Efficacy & Reference \\
\hline \multirow[t]{3}{*}{ Protein based } & S1 & S1 & Mice & $\mathrm{Nab}$ & Not tested & Wang et al., 2015 \\
\hline & rRBD-FC & S377-588 & Ad/hDPP4-mice & T-cell, Nab & Protective & Ma et al., 2014 \\
\hline & rNTD & S18-353 & Ad/hDPP4-mice & T-cell, Nab & Protective & Jiaming et al., 2017 \\
\hline \multirow[t]{3}{*}{ Recombinant viral vectors } & BNSP333-S1 & S1 & Ad/hDPP4-mice & $\mathrm{Nab}$ & Protective & Wirblich et al., 2017 \\
\hline & S377-588-Fc & S & Ad/hDPP4-mice & T-cell, Nab & Not tested & Tang et al., 2015 \\
\hline & VRP-S & S & 288/330+/+mice & $\mathrm{Nab}$ & Protective & Cockrell et al., 2016 \\
\hline \multirow[t]{2}{*}{ DNA vaccine } & pcDNA3.1-S1 & S1 & Ad5/hDPP4-mice & T-cell, Nab & Protective & Chi et al., 2017 \\
\hline & pVax1-S & S & Non human primates & T-cell, Nab & Protective & Muthumani et al., 2015 \\
\hline
\end{tabular}


The screening of dominant immunogens based on the availability of genome sequence data is crucial for designing novel vaccines, which is assisted by immunoinformatics (Firbas et al., 2006). The epitope directed lead design was one of the critical steps involved in the lead identification by immunoinformatics approaches (Shi et al., 2015). MHC-I restrained CD8+ cytotoxic T-lymphocytes (CTLs) identification provides profound insight in designing novel antiviral agents (Terry et al., 2015).

In conclusion, MERS-CoV infection continued to be fatal disease and has emerged as one of the epidemic concern. Irrespective of the various studies conducted to determine the distribution, the exact intermediates remain unidentified. There are various animal models available which provided profound insight in understanding the transmission and pathogenecity of the virus in human. The common pathogenesis mechanisms of the virus such as DPP4, PLpro, accessory proteins like p4a and membrane $M$ protein provided significant insight for the screening of novel drug targets for vaccine development. The detailed understanding of the binding mechanism of various

\section{REFERENCES}

Abd, E. W. A., Patel, P., Heidenreich, D., Hufert, F. T., and Weidmann, M. (2013). Reverse transcription recombinase polymerase amplification assay for the detection of Middle East respiratory syndrome coronavirus. PLoS Curr. 5:ecurrents.outbreaks.62df1c7c75ffc96cd59034531e2e8364. doi: 10.1371/ currents.outbreaks.62df1c7c75ffc96cd59034531e2e8364

Aderem, A., Adkins, J. N., Ansong, C., Galagan, J., Kaiser, S., Korth, M. J., et al. (2011). A systems biology approach to infectious disease research: innovating the pathogen-host research paradigm. mBio 2:e00325-10. doi: 10.1128/mBio. 00325-10 e00325-10,PMID:21285433

Agostini, M. L., Andres, E. L., Sims, A. C., Graham, R. L., Sheahan, T. P., Lu, X., et al. (2018). Coronavirus susceptibility to the antiviral Remdesivir (GS-5734) is mediated by the viral polymerase and the proofreading exoribonuclease. $m B i o$ 9:e00221-18. doi: 10.1128/mBio.00221-18e00221-18

Agrawal, A. S., Garron, T., Tao, X., Peng, B. H., Wakamiya, M., Chan, T. S., et al. (2015). Generation of a transgenic mouse model of middle east respiratory syndrome coronavirus infection and disease. J. Virol. 89, 3659-3670. doi: 10.1128/JVI.03427-14

Agrawal, A. S., Tao, X., Algaissi, A., Garron, T., Narayanan, K., Peng, B. H., et al. (2016). Immunization with inactivated Middle East Respiratory Syndrome coronavirus vaccine leads to lung immunopathology on challenge with live virus. Hum. Vaccin. Immunother. 12, 2351-2356. doi: 10.1080/21645515.2016. 1177688

Albarrak, A., Stephens, G., Hewson, R., and Memish, Z. (2012). Recovery from severe novel coronavirus infection. Saudi Med. J. 33, 1265-1269.

Al-Qahtani, A. A., Lyroni, K., Aznaourova, M., Tseliou, M., Al-Anazi, M. R., AlAhdal, M. N., et al. (2017). Middle east respiratory syndrome corona virus spike glycoprotein suppresses macrophage responses via DPP4-mediated induction of IRAK-M and PPAR $\gamma$. Oncotarget 8, 9053-9066. doi: 10.18632/oncotarget. 14754

Alsaad, K. O., Hajeer, A. H., Al Balwi, M., Al Moaiqel, M., Al Oudah, N., Al Ajlan, A., et al. (2018). Histopathology of Middle East respiratory syndrome corona virus (MERS-CoV) infection - clinicopathological and ultrastructural study. Histopathology 72, 516-524. doi: 10.1111/his.13379

Alshukairi, A. N., Zheng, J., Zhao, J., Nehdi, A., Baharoon, S. A., Layqah, L., et al. (2018). High prevalence of MERS-CoV infection in camel workers in Saudi Arabia. mBio 9:e01985-18. doi: 10.1128/mBio.0198518e01985-18

Al-Tawfiq, J. A., Momattin, H., Dib, J., and Memish, Z. A. (2014). Ribavirin and interferon therapy in patients infected with the Middle East respiratory syndrome coronavirus: an observational study. Int. J. Infect. Dis. 20, 42-46. doi: $10.1016 /$ j.ijid.2013.12.003 inhibitors toward the structural, non-structural, and accessory proteins of the virus probably provide profound insight for lead development. The integration of genome analysis, proteomics studies, immunoinformatics, and systems biology approaches on various animal models have made the recognition of new targets and lead molecules much easier in than the approaches available during earlier time. By considering MERS-CoV infections as one of the great public threats, there is high demand for undertaking the coronavirus research at the deeper molecular level to understand the mechanism of viral infection, development of advanced and rapid detection methods and futuristic therapeutic strategies to combat MERS-CoV infections.

\section{AUTHOR CONTRIBUTIONS}

SS, SC, SP, SK, and VS collected data and prepared the complete manuscript. Further, SS reviewed, revised, and edited the manuscript.

Arabi, Y. M., Balkhy, H. H., Hayden, F. G., Bouchama, A., Luke, T., Baillie, J. K., et al. (2017). Middle East Respiratory Syndrome. N. Engl. J. Med. 376, 584-594. doi: 10.1056/NEJMsr1408795

Assiri, A., Al-Tawfiq, J., and Al-Rabeeah, A. (2013a). Epidemiological, demographic, and clinical characteristics of 47 cases of Middle East respiratory syndrome corona virus disease from Saudi Arabia: a descriptive study. Lancet Infect. Dis. 13, 752-761. doi: 10.1016/S1473-3099(13)70204-4

Assiri, A., McGeer, A., Perl, T. M., Price, C. S., Al Rabeeah, A. A., Cummings, D. A., et al. (2013b). KSA MERS-CoV investigation team. hospital outbreak of middle east respiratory syndrome coronavirus. N. Engl. J. Med. 369:886. doi: 10.1056/NEJMoa1306742

Baseler, L., de Wit, E., and Feldmann, H. (2016). A comparative review of animal models of middle east respiratory syndrome coronavirus infection. Vet. Pathol. 53, 521-531. doi: 10.1177/0300985815620845

Batool, M., Shah, M., Patra, M. C., Yesudhas, D., and Choi, S. (2017). Structural insights into the Middle East respiratory syndrome coronavirus 4a protein and its dsRNA binding mechanism. Sci. Rep. 7:11362. doi: 10.1038/s41598-01711736-6

Bauch, C. T., and Oraby, T. (2013). Assessing the pandemic potential of MERSCoV. Lancet 382, 662-664. doi: 10.1016/S0140-6736(13)61504-4

Breban, R., Riou, J., and Fontanet, A. (2013). Inter-human transmissibility of Middle East respiratory syndrome corona virus: estimation of pandemic risk. Lancet 382, 694-699. doi: 10.1016/S0140-6736(13)61492-0

Buchholz, U., Müller, M., Nitsche, A., Sanewski, A., Wevering, N., Bauer-Balci, T., et al. (2013). Contact investigation of a case of human novel corona virus infection treated in a German hospital, October-November 2012. Euro. Surveill 18:20406.

Canton, J., Fehr, A. R., Fernandez-Delgado, R., Gutierrez-Alvarez, F. J., SanchezAparicio, M. T., García-Sastre, A., et al. (2018). MERS-CoV 4 b protein interferes with the NF-кB-dependent innate immune response during infection. PLoS Pathog. 14:e1006838. doi: 10.1371/journal.ppat.1006838

Cauchemez, S., Fraser, C., Van, K. M. D., Donnelly, C. A., Riley, S., and Rambaut, A. (2014). Middle East respiratory syndrome corona virus: quantification of the extent of the epidemic, surveillance biases, and transmissibility. Lancet Infect. Dis. 14, 50-56. doi: 10.1016/S1473-3099(13) 70304-9

Chafekar, A., and Fielding, B. C. (2018). MERS-CoV: Understanding the latest human Corona virus threat. Viruses 10:E93. doi: 10.3390/v10020093

Chan, J. F., Chan, K. H., Choi, G. K., To, K. K., Tse, H., Cai, J. P., et al. (2013a). Differential cell line susceptibility to the emerging novel human betacoronavirus 2c EMC/2012: implications for disease pathogenesis and clinical manifestation. J. Infect. Dis. 207, 1743-1752. doi: 10.1093/infdis/ jit123 
Chan, J. F., Lau, S. K., and Woo, P. C. (2013b). The emerging novel Middle East respiratory syndrome corona virus: the 'knowns' and 'unknowns'. J. Formos. Med. Assoc. 112, 372-381. doi: 10.1016/j.jfma.2013.05.010

Chan, J. F., Li, K. S., To, K. K., Cheng, V. C., Chen, H., and Yuen, K. Y. (2012). Is the discovery of the novel human betacoronavirus 2c EMC/2012 ( HCoVEMC) the beginning of another SARS-like pandemic? J. Infect. 65, 477-489. doi: 10.1016/j.jinf.2012.10.002

Chi, H., Zheng, X., Wang, X., Wang, C., Wang, H., Gai, W., et al. (2017). DNA vaccine encoding Middle East respiratory syndrome coronavirus S1 protein induces protective immune responses in mice. Vaccine 35, 2069-2075. doi: 10.1016/j.vaccine.2017.02.063

Chowell, G., and Nishiura, H. (2014). Transmission dynamics and control of Ebola virus disease (EVD): a review. BMC Med. 12:196. doi: 10.1186/s12916-0140196-0

Chu, H., Zhou, J., Wong, B. H., Li, C., Chan, J. F., Cheng, Z. S., et al. (2016). Middle east respiratory syndrome coronavirus efficiently infects human primary $\mathrm{T}$ lymphocytes and activates the extrinsic and intrinsic apoptosis pathways. J. Infect. Dis. 213, 904-914. doi: 10.1093/infdis/jiv380

Clasman, J. R., Báez-Santos, Y. M., Mettelman, R. C., O’Brien, A., Baker, S. C., and Mesecar, A. D. (2017). X-ray structure and enzymatic activity profile of a core papain-like protease of MERS coronavirus with utility for structure-based drug design. Sci. Rep. 7:40292. doi: 10.1038/srep40292

Cockrell, A. S., Yount, B. L., Scobey, T., Jensen, K., Douglas, M., Beall, A., et al. (2016). A mouse model for MERS coronavirus-induced acute respiratory distress syndrome. Nat. Microbiol. 2:16226. doi: 10.1038/nmicrobiol. 2016.226

Coleman, C. M., Sisk, J. M., Halasz, G., Zhong, J., Beck, S. E., Matthews, K. J., et al. (2017). CD8 + T Cells and macrophages regulate pathogenesis in a mouse model of middle east respiratory syndrome. J. Virol. 91:e01825-16.

Cong, Y., Hart, B. J., Gross, R., Zhou, H., Frieman, M., Bollinger, L., et al. (2018). MERS-CoV pathogenesis and antiviral efficacy of licensed drugs in human monocyte-derived antigen-presenting cells. PLoS One 13:e0194868. doi: 10. 1371/journal.pone.0194868

Conzade, R., Grant, R., Malik, M. R., Elkholy, A., Elhakim, M., Samhouri, D., et al. (2018). Reported direct and indirect contact with dromedary camels among laboratory-confirmed MERS-CoV cases. Viruses 10:E425. doi: 10.3390/ v10080425

Corman, V. M., Albarrak, A. M., Omrani, A. S., Albarrak, M. M., Farah, M. E., Almasri, M., et al. (2016). Viral shedding and antibody response in 37 patients with Middle East Respiratory Syndrome Coronavirus infection. Clin. Infect. Dis. 62, 477-483. doi: 10.1093/cid/civ951

Corman, V. M., Eckerle, I., Bleicker, T., Zaki, A., Landt, O., Eschbach-Bludau, M., et al. (2012a). Detection of a novel human coronavirus by real-time reversetranscription polymerase chain reaction. Euro. Surveill. 17:20285. doi: 10.2807/ ese.17.39.20285-en

Corman, V. M., Muller, M. A., Costabel, U., Timm, J., Binger, T., and Meyer, B. (2012b). Assays for laboratory confirmation of novel human coronavirus (hCoV-EMC) infections. Euro. Surveill. 17:1.

de Groot, R. J., Baker, S. C., Baric, R. S., Brown, C. S., Drosten, C., Enjuanes, L., et al. (2013). Middle East respiratory syndrome coronavirus (MERS-CoV): announcement of the Coronavirus Study Group. J. Virol. 87, 7790-7792. doi: 10.1128/JVI.01244-13

de Sousa, R., Reusken, C., and Koopmans, M. (2014). MERS corona virus: Data gaps for laboratory preparedness. J. Clin. Virol. 59, 4-11. doi: 10.1016/j.jcv.2013. 10.030

de Wit, E., Prescott, J., Baseler, L., Bushmaker, T., Thomas, T., Lackemeyer, M. G., et al. (2013a). The Middle East respiratory syndrome coronavirus (MERS-CoV) does not replicate in Syrian hamsters. PLoS One 8:e69127. doi: 10.1371/journal. pone.0069127

de Wit, E., Rasmussen, A. L., Falzarano, D., Bushmaker, T., Feldmann, F., and Brining, D. L. (2013b). Middle East respiratory syndrome coronavirus (MERS-CoV) causes transient lower respiratory tract infection in rhesus macaques. Proc. Natl. Acad. Sci. U.S.A. 110, 16598-16603. doi: 10.1073/pnas. 1310744110

Denayer, T., Stöhr, T., and Roy, M. V. (2014). Animal models in translational medicine: Validation and prediction. New Horiz. Transl. Med. 2, 5-11. doi: 10.1016/j.nhtm.2014.08.001
Doremalen, N. V., and Munster, V. J. (2015). Animal models of middle east respiratory syndrome coronavirus infection. Antiviral Res. 22, 28-38. doi: 10.1016/j.antiviral.2015.07.005

Drosten, C. (2013). Is MERS another SARS? Lancet Infect. Dis. 13, 727-728.

Drosten, C., Günther, S., Preiser, W., van der Werf, S., Brodt, H. R., Becker, S., et al. (2003). Identification of a novel coronavirus in patients with severe acute respiratory syndrome. N. Engl. J. Med. 348, 1967-1976. doi: 10.1056/ NEJMoa030747

Drosten, C., Meyer, B., Müller, M. A., Corman, V. M., Al-Masri, M., Hossain, R., et al. (2014). Transmission of MERS-coronavirus in household contacts. N Engl J Med. 371, 828-835. doi: 10.1056/NEJMoa1405858

Drosten, C., Seilmaier, M., and Corman, V. (2013). Clinical features and virological analysis of a case of Middle East respiratory syndrome corona virus infection. Lancet Infect. Dis. 13, 745-751. doi: 10.1016/S1473-3099(13)70154-3

Du, L., He, Y., Zhou, Y., Liu, S., Zheng, B. J., and Jiang, S. (2009). The spike protein of SARS-CoV-a target for vaccine and therapeutic development. Nat. Rev. Microbiol. 7, 226-236. doi: 10.1038/nrmicro2090

Du, L., Zhao, G., Kou, Z., Ma, C., Sun, S., and Poon, V. K. (2013). Identification of a receptor-binding domain in the $S$ protein of the novel human corona virus Middle East respiratory syndrome corona virus as an essential target for vaccine development. J. Virol. 87, 9939-9942. doi: 10.1128/JVI.01048-13

Durai, P., Batool, M., Shah, M., and Choi, S. (2015). Middle East respiratory syndrome corona virus: transmission, virology and therapeutic targeting to aid in outbreak control. Exp. Mol. Med. 47:e181. doi: 10.1038/emm.2015.76

Eckerle, I., Corman, V. M., Muller, M. A., Lenk, M., Ulrich, R. G., and Drosten, C. (2014). Replicative capacity of MERS coronavirus in livestock cell lines. Emerg. Infect. Dis. 20, 276-279. doi: 10.3201/eid2002.131182

Falzarano, D., de Wit, E., Feldmann, F., Rasmussen, A. L., Okumura, A., and Peng, X. (2014). Infection with MERS-CoV causes lethal pneumonia in the common marmoset. PLoS Pathog. 10:e1004250. doi: 10.1371/journal.ppat. 1004250

Faure, E., Poissy, J., Goffard, A., Fournier, C., Kipnis, E., Titecat, M., et al. (2014). Distinct immune response in two MERS-CoV-infected patients: can we go from bench to bedside? PLoS One 9:e88716. doi: 10.1371/journal.pone.0088716

Firbas, C., Jilma, B., Tauber, E., Buerger, V., Jelovcan, S., and Lingnau, K. (2006). Immunogenicity and safety of a novel therapeutic hepatitis $\mathrm{C}$ virus (HCV) peptide vaccine: a randomized, placebo controlled trial for dose optimization in 128 healthy subjects. Vaccine 24, 4343-4353. doi: 10.1016/j.vaccine.2006.03.009

Forni, D., Giulia, F., Rachele, C., Gioia, D. L., Pozzoli, P., and Al-Daghri, N. (2015). The heptad repeat region is a major selection target in MERS-CoV and related corona viruses. Sci. Rep. 25:14480. doi: 10.1038/srep 14480

Fouchier, R. A., Schneeberger, P. M., Rozendaal, F. W., Broekman, J. M., Kemink, S. A., Munster, V., et al. (2004). Avian influenza A virus (H7N7) associated with human conjunctivitis and a fatal case of acute respiratory distress syndrome. Proc. Natl. Acad. Sci. U.S.A. 101, 1356-1361. doi: 10.1073/pnas.0308352100

Fung, T. S., and Liu, D. X. (2014). Corona virus infection, ER stresses apoptosis and innate immunity. Front. Microbiol. 5:296. doi: 10.3389/fmicb.2014.00296

Gao, H., Yao, H., Yang, S., and Li, L. (2016). From SARS to MERS: evidence and speculation. Front Med. 10, 377-382. doi: 10.1007/s11684-016-0466-7

Gorbalenya, A. E., Enjuanes, L., Ziebuhr, J., and Snijder, E. J. (2006). Nidovirales: evolving the largest RNA virus genome. Virus Res. 117, 17-37. doi: 10.1016/j. virusres.2006.01.017

Guery, B., Poissy, J., and el Mansouf, L. (2013). Clinical features and viral diagnosis of two cases of infection with Middle East Respiratory Syndrome corona virus: a report of nosocomial transmission. Lancet 381, 2265-2272. doi: 10.1016/S01406736(13)60982-4

Haagmans, B. L., van den Branda, J. M. A., Provaciaa, L. B., Raja, V. S., Stittelaarb, K. J., Getua, S., et al. (2015). Asymptomatic middle east respiratory syndrome coronavirus infection in rabbits. J. Virol. 89, 6131-6135. doi: 10.1128/JVI. 00661- 15

Hamre, D., and Procknow, J. J. (1966). A new virus isolated from the human respiratory tract. Proc Soc Exp Biol Med. 121, 190-193. doi: 10.3181/00379727121-30734

Harcourt, J. L., Rudoler, N., Tamin, A., Leshemm, E., Rasis, M., Giladi, M., et al. (2018). The prevalence of Middle East respiratory syndrome coronavirus (MERS-CoV) antibodies in dromedary camels in Israel. Zoonoses Public Health doi: 10.1111/zph.12482 [Epub ahead of print]. 
Harrigan, J. A., Jacq, X., Martin, N. M., and Jackson, S. P. (2018). Deubiquitylating enzymes and drug discovery: emerging opportunities. Nat. Rev. Drug Discov. 17, 57-78. doi: 10.1038/nrd.2017.152

Health Protection Agency. (2013). Evidence of person-to-person transmission within a family cluster of novel corona virus infections, United Kingdom, February. Euro Surveill. 18:20427.

Henderson, D. A., and Moss, B. (1999). Recombinant Vaccinia Virus Vaccines. Vaccines 6, 43-46.

Hou, L., and Zhao, H. (2013). A review of post-GWAS prioritization approaches. Front. Genet. 4:280. doi: 10.3389/fgene.2013.00280

Houser, K. V., Broadbent, A. J., Gretebeck, L., Vogel, L., Lamirande, E. W., Sutton, T., et al. (2017). Enhanced inflammation in New Zealand white rabbits when MERS-CoV reinfection occurs in the absence of neutralizing antibody. PLoS Pathog. 13:e1006565. doi: 10.1371/journal.ppat.1006565

Houser, K. V., Gretebeck, L., Ying, T., Wang, Y., Vogel, L., Lamirande, E. W., et al. (2016). Prophylaxis with a Middle East respiratory syndrome coronavirus (MERS-CoV)-specific human monoclonal antibody protects rabbits from MERS-CoV infection. J. Infect. Dis. 213, 1557-1561. doi: 10.1093/infdis/ jiw080

Huang, P., Wang, H., Cao, Z., Jin, H., Chi, H., Zhao, J., et al. (2018). A rapid and specific assay for the detection of MERS-CoV. Front. Microbiol. 9:1101. doi: 10.3389/fmicb.2018.01101

Hui, D. S., Azhar, E. I., Kim, Y. J., Memish, Z. A., Oh, M. D., and Zumla, A. (2018). Middle East respiratory syndrome corona virus: risk factors and determinants of primary, household, and nosocomial transmission. Lancet Infect. Dis. 18, e217-e227. doi: 10.1016/S1473-3099(18)30127-0

Jiaming, L., Yanfeng, Y., Yao, D., Yawei, H., Linlin, B., Baoying, H., et al. (2017). The recombinant $\mathrm{N}$-terminal domain of spike proteins is a potential vaccine against Middle East respiratory syndrome coronavirus (MERS-CoV) infection. Vaccine 35, 10-18. doi: 10.1016/j.vaccine.2016.11.064

Kandeil, A., Gomaa, M., Shehata, M., El-Taweel, A., Kayed, A., Abiadh, A., et al. (2019). Middle East respiratory syndrome coronavirus infection in non-camelid domestic mammals. Emerg. Microbes Infect. 8, 103-108. doi: 10.1080/22221751. 2018.1560235

Kim, T. (2016). The Korean Ministry of Health \& Welfare. Press release: MERS statistics. Sejong: Ministry of Health \& Welfare. Available at: http://english.mw.go.kr/front_eng/sg/ssg0111vw.jsp?PAR_MENU_ID1001\& MENU_ID100111\&page1\&CONT_SEQ324470 [accessed July 15, 2016].

Kuiken, T., Fouchier, R. A., Schutten, M., Rimmelzwaan, G. F., van Amerongen, G., van Riel, D., et al. (2003). Newly discovered coronavirus as the primary cause of severe acute respiratory syndrome. Lancet 362, 263-270. doi: 10.1016/S01406736(03)13967-0

Lau, S. K., Lau, C. C., Chan, K. H., Li, C. P., Chen, H., Jin, D. Y., et al. (2013). Delayed induction of proinflammatory cytokines and suppression of innate antiviral response by the novel Middle East respiratory syndrome coronavirus: implications for pathogenesis and treatment. J. Gen. Virol. 94( $\mathrm{Pt} 12)$, 2679-2690. doi: 10.1099/vir.0.055533-0

Lau, S. K. P., Wong, A. C. P., Lau, T. C. K., and Woo, P. C. Y. (2017). Molecular Evolution of MERS Corona virus: dromedaries as a Recent Intermediate Host or Long-Time Animal Reservoir? Int. J. Mol. Sci. 18:E2138. doi: 10.3390/ ijms 18102138

Law, G. L., Korth, M. J., Benecke, A. G., and Katze, M. G. (2013). Systems virology: host-directed approaches to viral pathogenesis and drug targeting. Nat. Rev. Microbiol. 11, 455-466. doi: 10.1038/nrmicro3036

Lorenzen, E., Follmann, F., Jungersen, G., and Agerholm, J. S. (2015). A review of the human vs. porcine female genital tract and associated immune system in the perspective of using minipigs as a model of human genital Chlamydia infection. Vet. Res. 46:116. doi: 10.1186/s13567-015-0241-9

Lui, P. L., Wong, L. Y. R., Fung, C. L., Siu, K. L., Yeung, M. L., Yuen, K. S., et al. (2016). Middle East respiratory syndrome coronavirus M protein suppresses type I interferon expression through the inhibition of TBK1dependent phosphorylation of IRF3. Emerg. Microbes Infect. 5:e39. doi: 10.1038/ emi.2016.33

Ma, C., Wang, L., Tao, X., Zhang, N., Yang, Y., Tseng, C. K., et al. (2014). Searching for an ideal vaccine candidate among different MERS coronavirus receptor-binding fragments-The importance of immunofocusing in subunit vaccine design. Vaccine 32, 6170-6176. doi: 10.1016/j.vaccine.2014. 08.086
Marra, M. A., Jones, S. J., Astell, C. R., Holt, R. A., Brooks-Wilson, A., Butterfield, Y. S., et al. (2003). The genome sequence of the SARS-associated coronavirus. Science 300, 1399-1404. doi: 10.1126/science. 1085953

Masters, P. (2006). The molecular biology of corona viruses. Adv. Virus Res. 66, 193-292. doi: 10.1016/S0065-3527(06)66005-3

McDermott, J. E., Shankaran, H., Eisfeld, A. J., Belisle, S. E., Neuman, G., and Li, C. (2011). Conserved host response to highly pathogenic avian-influenza virus infection in human cell culture, mouse and macaque model systems. BMC Syst. Biol. 5:190. doi: 10.1186/1752-0509-5-190

Memish, Z., Mishra, N., and Olival, K. (2013a). Middle East respiratory syndrome corona virus in bats, Saudi Arabia. Emerg. Infect. Dis. 19, 1819-1823. doi: 10.3201/eid1911.131172

Memish, Z., Zumla, A., and Assiri, A. (2013b). Middle East respiratory syndrome corona virus infections in health care workers. N. Engl. J. Med. 2013, 884-886. doi: 10.1016/j.ajic.2017.08.010

Memish, Z. A., Assiri, A., Alhakeem, R., Yezli, S., Almasri, M., Zumla, A., et al. (2014a). Middle East Respiratory Syndrome Corona virus, MERS-CoV. Conclusions from the 2nd scientific advisory board meeting of the WHO collaborating center for mass gathering medicine, Riyadh. Int. J. Infect. Dis. 24, 51-53. doi: 10.1016/j.ijid.2014.05.001

Memish, Z. A., Assiri, A. M., and Al-Tawfiq, J. A. (2014b). Middle East respiratory syndrome corona virus (MERS-CoV) viral shedding in the respiratory tract: an observational analysis with infection control implications. Int. J. Infect. Dis. 29, 307-308. doi: 10.1016/j.ijid.2014.10.002

Menachery, V. D., Eisfeld, A. J., Schäfer, A., Josset, L., Sims, A. C., Proll, S., et al. (2014). Pathogenic influenza viruses and coronaviruses utilize similar and contrasting approaches to control interferon-stimulated gene responses. $m B i o$ 5:e01174-14. doi: 10.1128/mBio.01174-14 e01174-14,PMID:24846384

Menachery, V. D., Mitchell, H. D., Cockrell, A. S., Gralinski, L. E., Yount, B. L. Jr., Graham, R. L., et al. (2017). MERS-CoV Accessory ORFs play key role for infection and pathogenesis. mBio 8:e00665-17. doi: 10.1128/mBio.0066517e00665-17

Menachery, V. D., Schäfer, A., Burnum-Johnson, K. E., Mitchell, H. D., Eisfeld, A. J., Walters, K. B., et al. (2018). MERS-CoV and H5N1 influenza virus antagonize antigen presentation by altering the epigenetic landscape. Proc. Natl. Acad. Sci. U.S.A. 115, E1012-E1021. doi: 10.1073/pnas.1706928115

Meyer, B., Drosten, C., and Muller, M. A. (2014). Serological assays for emerging corona viruses: challenges and pitfalls. Virus Res. 194, 175-183. doi: 10.1016/j. virusres.2014.03.018

Meyer, B., García-Bocanegra, I., Wernery, U., Wernery, R., Sieberg, A., Müller, M. A., et al. (2015). Serologic assessment of possibility for MERS-CoV infection in equids. Emerg. Infect. Dis. 21, 181-182. doi: 10.3201/eid2101.141342

Mielech, A. M., Kilianski, A., Baez-Santos, Y. M., Mesecar, A. D., and Baker, S. C. (2014). MERS-CoV papain-like protease has deISGylating and deubiquitinating activities. Virology 45, 64-70. doi: 10.1016/j.virol.2013.11.040

Mitchell, H. D., Eisfeld, A. J., Sims, A. C., McDermott, J. E., Matzke, M. M., and Webb-Robertson, B. J. (2013). A network integration approach to predict conserved regulators related to pathogenicity of influenza and SARS$\mathrm{CoV}$ respiratory viruses. PLoS One 8:e69374. doi: 10.1371/journal.pone. 0069374

Muller, M. A., Raj, V. S., Muth, D., Meyer, B., Kallies, S., Smits, S. L., et al. (2012). Human coronavirus EMC does not require the SARS-coronavirus receptor and maintains broad replicative capability in mammalian cell lines. mBio 3:e00515-12. doi: 10.1128/mBio.00515-12

Mustafa, S., Balkhy, H., and Gabere, M. N. (2017). Current treatment options and the role of peptides as potential therapeutic components for Middle East Respiratory Syndrome (MERS): a review. J. Infect. Public Health 11, 9-17. doi: 10.1016/j.jiph.2017.08.009

Mustafa, S., Balkhy, H., and Gabere, M. N. (2018). Current treatment options and the role of peptides as potential therapeutic components for middle east respiratory syndrome (MERS): a review. J. Infect. Public Health 11, 9-17. doi: 10.1016/j.jiph.2017.08.009

Muth, D., Corman, V. M., Meyer, B., Assiri, A., Al-Masri, M., and Farah, M. (2015). Infectious Middle East respiratory Syndrome Corona virus excretion and serotype variability based on live virus isolates from patients in Saudi Arabia. J. Clin. Microbiol. 53, 2951-2955. doi: 10.1128/JCM.01368-15

Muthumani, K., Falzarano, D., Reuschel, E. L., Tingey, C., Flingai, S., Villarreal, D. O., et al. (2015). A synthetic consensus anti-spike protein DNA vaccine 
induces protective immunity against Middle East respiratory syndrome coronavirus in nonhuman primates. Sci. Transl. Med. 7:301ra132. doi: 10.1126/ scitranslmed.aac7462

Ng, D. L., Al Hosani, F., Keating, M. K., Gerber, S. I., Jones, T. L., Metcalfe, M. G., et al. (2016). Clinicopathologic, Immunohistochemical, and Ultra structural Findings of a Fatal Case of Middle East Respiratory Syndrome Corona virus Infection in the United Arab Emirates, April 2014. Am. J. Pathol. 186, 652-658. doi: 10.1016/j.ajpath.2015.10.024

Oh, M. D., Park, W. B., Park, S. W., Choe, P. G., Bang, J. H., Song, K. H., et al. (2018). Middle East respiratory syndrome: what we learned from the 2015 outbreak in the Republic of Korea. Korean J. Intern. Med. 33, 233-246. doi: $10.3904 / \mathrm{kjim} .2018 .031$

Ohnuma, K., Haagmans, B. L., Hatano, R., Raj, V. S., Mou, H., Iwata, S., et al. (2013). Inhibition of Middle East respiratory syndrome coronavirus infection by anti-CD26 monoclonal antibody. J. Virol. 87, 13892-13899. doi: 10.1128/JVI. 02448-13

Okba, N. M., Raj, V. S., and Haagmans, B. L. (2017). Middle East respiratory syndrome coronavirus vaccines: current status and novel approaches. Curr. Opin. Virol. 23, 49-58. doi: 10.1016/j.coviro.2017. 03.007

Omrani, A., Matin, M., Haddad, Q., Al-Nakhli, D., Memish, Z., and Albarrak, A. (2013). A family cluster of Middle East Respiratory Syndrome Corona virus infections related to a likely unrecognized asymptomatic or mild case. Int. J. Infect. Dis. 17:72. doi: 10.1016/j.ijid.2013.07.001

Pallesen, J., Wang, N., Corbett, K. S., Wrapp, D., Kirchdoerfer, R. N., Turner, H. L., et al. (2017). Immunogenicity and structures of a rationally designed prefusion MERS-CoV spike antigen. Proc. Natl. Acad. Sci. U.S.A. 114, E7348-E7357. doi: 10.1073/pnas.1707304114

Park, J. E., Li, K., Barlan, A., Fehr, A. R., Perlman, S., McCray, P. B., et al. (2016). Proteolytic processing of middle east respiratory syndrome coronavirus spikes expands virus tropism. Proc. Natl. Acad. Sci. U.S.A. 113, 12262-12267. doi: 10.1073/pnas.1608147113

Park, W. B., Perera, R. A., Choe, P. G., Lau, E. H., Choi, S. J., Chun, J. Y., et al. (2015). Kinetics of serologic responses to MERS Coronavirus Infection in Humans. South Korea. Emerg. Infect. Dis. 21, 2186-2189. doi: 10.3201/eid2112. 151421

Pascal, K. E., Colemanb, C. M., Mujicaa, A. O., Kamata, V., Badithea, A., Fairhursta, J., et al. (2015). Pre- and postexposure efficacy of fully human antibodies againt Spike protein in a novel humanized mouse model of MERSCoV infection. Proc. Natl. Acad. Sci. U.S.A. 112, 8738-8743. doi: 10.1073/pnas. 1510830112

Peck, K. M., Cockrell, A. S., Yount, B. L., Scobey, T., Baric, R. S., and Heise, M. T. (2015). Glycosylation of mouse DPP4 plays a role in inhibiting Middle East Respiratory Syndrome Coronavirus infection. J. Virol. 89, 4696-4699. doi: 10.1128/JVI.03445-14

Perera, R. A., Wang, P., Gomaa, M. R., El-Shesheny, R., Kandeil, A., Bagato, O., et al. (2013). Seroepidemiology for MERS coronavirus using microneutralisation and pseudoparticle virus neutralisation assays reveal a high prevalence of antibody in dromedary camels in Egypt. Euro. Surveill. 18:20574.

Perlman, S. (2015). Research Driven by Curiosity: the Journey from basic molecular biology and virology to studies of human pathogenic corona viruses. PLoS Pathog. 11:e1005023. doi: 10.1371/journal.ppat.10 05023

Perlman, S., and Netland, J. (2009). Coronaviruses post-SARS: update on replication and pathogenesis. Nat. Rev. Microbiol. 7, 439-450. doi: 10.1038/ nrmicro2147

Puzelli, S., Azzi, A., Santini, M. G., Di, M. A., Facchini, M., and Castrucci, M. R. (2013). Investigation of an imported case of Middle East Respiratory Syndrome Corona virus (MERS-CoV) infection in Florence, Italy, May to June 2013. Euro. Surveill. 18:1.

Rabaan, A. A., Bazzi, A. M., Al-Ahmed, S. H., and Al-Tawfiq, J. A. (2017). Molecular aspects of MERS-CoV. Front. Med. 11, 365-377. doi: 10.1007/ s11684-017-0521-z

Rabouw, H. H., Langereis, M. A., Knaap, R. C. M., Dalebout, T. J., Canton, J., Sola, I., et al. (2016). Middle east respiratory coronavirus accessory protein 4a inhibits PKR-mediated antiviral stress responses. PLoS Pathog. 12:e1005982. doi: 10.1371/journal.ppat.1005982
Raj, V. S., Mou, H., Smits, S. L., Dekkers, D. H., Müller, M. A., Dijkman, R., et al. (2013). Dipeptidyl peptidase 4 is a functional receptor for the emerging human coronavirus-EMC. Nature 495, 251-254. doi: 10.1038/nature12005

Raj, V. S., Osterhaus, A. D., and Fouchier, R. A. (2014). MERS: emergence of a novel human coronavirus. Curr. Opin. Virol. 5, 58-62. doi: 10.1016/j.coviro.2014. 01.010

Rockx, B., Donaldson, E., Frieman, M., Sheahan, T., Corti, D., Lanzavecchia, A., et al. (2010). Escape from human monoclonal antibody neutralization affects in vitro and in vivo fitness of severe acute respiratory syndrome corona virus. J. Infect. Dis. 201, 946-955. doi: 10.1086/651022

Rota, P. A., Oberste, M. S., Monroe, S. S., Nix, W. A., Campagnoli, R., Icenogle, J. P., et al. (2003). Characterization of a novel coronavirus associated with severe acute respiratory syndrome. Science 300, 1394-1399. doi: 10.1126/science. 1085952

Selinger, C., Tisoncik-Go, J., Menachery, V. D., Agnihothram, S., Law, G. L., Chang, J., et al. (2014). Cytokine systems approach demonstrates differences in innate and pro-inflammatory host responses between genetically distinct MERS-CoV isolates. BMC Genomics 15:1161. doi: 10.1186/1471-216415-1161

Shehata, M. M., Gomaa, M. R., Ali, M. A., and Kayali, G. (2016). Middle East respiratory syndrome coronavirus: a comprehensive review. Front Med. 10, 120-136. doi: 10.1007/s11684-016-0430-6

Shi, J., Zhang, J., Li, S., Sun, J., Teng, Y., and Wu, M. (2015). Epitope-based vaccine target screening against highly pathogenic MERS-CoV: An in silico approach applied to emerging infectious diseases. PLoS One 10:e0144475. doi: 10.1371/ journal.pone.0144475

Shirato, K., Kawase, M., and Matsuyama, S. (2013). Middle East Respiratory Syndrome Coronavirus Infection Mediated by the Transmembrane Serine Protease TMPRSS2. J. Virol. 87, 12552-12561. doi: 10.1128/JVI.01890-13

Shirato, K., Yano, T., Senba, S., Akachi, S., Kobayashi, T., Nishinaka, T., et al. (2014). Detection of Middle East respiratory syndrome coronavirus using reverse transcription loop-mediated isothermal amplification (RT-LAMP). Virol J. 11, 139. doi: 10.1186/1743-422X-11-139

Smith, E. C., Blanc, H., Surdel, M. C., Vignuzzi, M., and Denison, M. R. (2013). Corona viruses lacking exoribonuclease activity are susceptible to lethal mutagenesis: evidence for proofreading and potential therapeutics. PLoS Pathog. 9:e1003565. doi: 10.1371/journal.ppat.1003565

Snijder, E. J., Bredenbeek, P. J., Dobbe, J. C., Thiel, V., Ziebuhr, J., Poon, L. L., et al. (2003). Unique and conserved features of genome and proteome of SARScoronavirus, an early split-off from the coronavirus group 2 lineage. J. Mol. Biol. 331, 991-1004. doi: 10.1016/S0022-2836(03)00865-9

Song, D., Ha, G., Serhan, W., Eltahir, Y., Yusof, M., and Hashem, F. (2015). Development and validation of a rapid immunochromatographic assay for detection of Middle East respiratory syndrome coronavirus antigen in dromedary camels. J. Clin. Microbiol. 53, 1178-1182. doi: 10.1128/JCM. 03096-14

Tang, J., Zhang, N., Tao, X., Zhao, G., Guo, Y., Tseng, C. T., et al. (2015). Optimization of antigen dose for a receptor-binding domain-based subunit vaccine against MERS coronavirus. Hum. Vaccin. Immunother. 11, 1244-1250. doi: 10.1080/21645515.2015.1021527

Tang, X. C. (2014). Identification of human neutralizing antibodies against MERS$\mathrm{CoV}$ and their role in virus adaptive evolution. Proc. Natl. Acad. Sci. U.S.A. 2014, E2018-E2026. doi: 10.1073/pnas.1402074111

Tao, X., Garron, T., Agrawal, A. S., Algaissi, A., Peng, B. H., Wakamiya, M., et al. (2015). Characterization and demonstration of the value of a lethal mouse model of middle east respiratory syndrome coronavirus infection and disease. J. Virol. 90, 57-67. doi: 10.1128/JVI.02009-15

Terry, F. E., Moise, L., Martin, R. F., Torres, M., Pilotte, N., and Williams, S. A. (2015). Time for T? Immunoinformatics addresses vaccine design for neglected tropical and emerging infectious diseases. Expert Rev. Vaccin. 14, 21-35. doi: $10.1586 / 14760584.2015 .955478$

van Boheemen, S., de Graaf, M., Lauber, C., Bestebroer, T. M., Raj, V. S., Zaki, A. M., et al. (2012). Genomic characterization of a newly discovered coronavirus associated with acute respiratory distress syndrome in humans. mBio 3:e0047312. doi: $10.1128 / \mathrm{mBio} .00473-12$

van den Brand, J. M., Smits, S. L., and Haagmans, B. L. (2015). Pathogenesis of Middle East respiratory syndrome coronavirus. J. Pathol. 235, 175-184. doi: $10.1002 /$ path. 4458 
van der Hoek, L., Pyrc, K., Jebbink, M. F., Vermeulen-Oost, W., Berkhout, R. J., Wolthers, K. C., et al. (2004). Identification of a new human coronavirus. Nat. Med. 10, 368-373. doi: 10.1038/nm1024

van Doremalen, N., Miazgowicz, K. L., Milne-Price, S., Bushmaker, T., Robertson, S., Scott, D., et al. (2014). Host species restriction of Middle East respiratory syndrome coronavirus through its receptor, dipeptidyl peptidase 4 . J. Virol. 88, 9220-9232. doi: 10.1128/JVI.00676-14

Vergara-Alert, J., Vidal, E., Bensaid, A., and Segalés, J. (2017). Searching for animal models and potential target species for emerging pathogens: experience gained from Middle East respiratory syndrome (MERS) coronavirus. One Health 3, 34-40. doi: 10.1016/j.onehlt.2017.03.001

Wang, C., Hua, C., Xia, S., Li, W., Lu, L., and Jiang, S. (2019). Combining a fusion inhibitory peptide targeting the MERS-CoV S2 protein HR1 domain and a neutralizing antibody specific for the S1 protein receptor-binding domain (RBD) showed potent synergism against pseudotyped MERS-CoV with or without mutations in RBD. Viruses 11:E31. doi: 10.3390/v11010031

Wang, L., Shi, W., Joyce, M. G., Modjarrad, K., Zhang, Y., Leung, K., et al. (2015). Evaluation of candidate vaccine approaches for MERS-CoV. Nat. Commun. 6:7712. doi: $10.1038 /$ ncomms 8712

Wang, N., Shi, X., Jiang, L., Zhang, S., Wang, D., Tong, P., et al. (2013). Structure of MERS-CoV spike receptor-binding domain complexed with human receptor DPP4. Cell Res. 23, 986-993. doi: 10.1038/cr.2013.92

Wang, Q. (2014). Bat origins of MERS-CoV supported by bat corona virus HKU4 usage of human receptor CD26. Cell Host Microbe 16, 328-337. doi: 10.1016/j. chom.2014.08.009

Wang, Q., Qi, J., Yuan, Y., Xuan, Y., Han, P., Wan, Y., et al. (2014). Bat origins of MERS-CoV supported by bat coronavirus HKU4 usage of human receptor CD26. Cell Host Microbe 16, 328-337. doi: 10.1016/j.chom.2014.08.009

Watson, J. T., Hall, A. J., Erdman, D. D., Swerdlow, D. L., and Gerber, S. I. (2014). Unraveling the mysteries of Middle East respiratory syndrome corona virus. Emerg. Infect. Dis. 20, 1054-1056. doi: 10.3201/eid2006.140322

Weiss, S. R., and Navas-Martin, S. (2005). Coronavirus pathogenesis and the emerging pathogen severe acute respiratory syndrome coronavirus. Microbiol. Mol. Biol. Rev. 69, 635-664. doi: 10.1128/MMBR.69.4.635-664.2005

Wirblich, C., Coleman, C. M., Kurup, D., Abraham, T. S., Bernbaum, J. G., Jahrling, P. B., et al. (2017). One-Health: a Safe, efficient, dual-use vaccine for humans and animals against Middle East Respiratory Syndrome Corona virus and Rabies Virus. J. Virol 91:e02040-16.e02040-16 doi: 10.1128/JVI. 02040-16

Woo, P. C., Lau, S. K., Chu, C. M., Chan, K. H., Tsoi, H. W., Huang, Y., et al. (2005). Characterization and complete genome sequence of a novel coronavirus, coronavirus HKU1, from patients with pneumonia. J. Virol. 79, 884-895. doi: 10.1128/JVI.79.2.884-895.2005

World Health Organization (2012). Novel Corona virus Infection - Update 2012. Available at: http://www.who.int/csr/don/2012_11_30/en/ [accessed February $9,2018]$.

World Health Organization (WHO) (2013a). Middle East Respiratory Syndrome Corona Virus Joint Kingdom of Saudi Arabial WHO mission. Available at: http://www.who.int/csr/disease/coronavirus_infections/MERSCov_WHO_ KSA_Mission_Jun13_.pdf [accessed January 30, 2018].

World Health Organization (2013b). Middle East Respiratory Syndrome Coronavirus (MERS-CoV) - update 2013. Available at: http://www.who. $\mathrm{int} / \mathrm{csr} / \mathrm{don} / 2013 \_12 \_31 / \mathrm{en} /$ [accessed February 9, 2018].

World Health Organization (2014). Middle East Respiratory Syndrome Coronavirus (MERS-CoV) - Saudi Arabia. Available at: http://www.who.int/csr/don/26december-2014-mers/en/ [accessed February 9, 2018].

World Health Organization (WHO) (2015a). Middle East Respiratory Syndrome Coronavirus (MERS-CoV) - Saudi Arabia. Available at: http://www.who.int/csr/ don/4-december-2015-mers-saudi-arabia/en/ [accessed February 9, 2018].

World Health Organization (WHO) (2015b). Summary and Risk Assessment of Current Situation in Republic of Korea and China. Available at: http://www.who. $\mathrm{int} / \mathrm{csr} /$ disease/coronavirus_infections/risk-assessment-19june2015/en/

World Health Organization (WHO) (2016a). Middle East Respiratory Syndrome Coronavirus (MERS-CoV) - Saudi Arabia. Available at: http://www.who.int/csr/ don/19-december-2016-2-mers-saudi-arabia/en/ [accessed February 9, 2018].

World Health Organization (WHO) (2016b). Middle East Respiratory Syndrome Corona Virus (MERS-CoV) WHO MERS-CoV Global Summary and risk assessment 5 December 2016 WHO/MERS/RA/16.1. Available at: https://www. who.int/emergencies/mers-cov/en/

World health Organization (WHO) (2017a). Middle East Respiratory Syndrome Corona Virus (MERS-CoV) - Oman. Available at: http://www.who.int/csr/don/ 10-november-2017-mers-oman/en/ [accessed December 1, 2017].

World Health Organization (WHO) (2017b). Middle East Respiratory Syndrome Coronavirus (MERS-CoV) - United Arab Emirates. Available at: http://www. who.int/csr/don/22-december-2017-mers-cov-united-arab-emirates/en/ [accessed February 9, 2018].

World Health Organization (WHO) (2018a). Middle East Respiratory Syndrome Coronavirus (MERS-CoV). Available at: https://www.who.int/emergencies/ mers-cov/en/

World Health Organization (WHO) (2018b). Middle East respiratory syndrome coronavirus (MERS-CoV) - Saudi Arabia. Available at: http://www.who.int/csr/ don/31-december-2018-mers-saudi-arabia/en/ [accessed December 31, 2018].

Xia, S., Liu, Q., Wang, Q., Sun, Z., Su, S., and Du, L. (2014). Middle East respiratory syndrome corona virus (MERS-CoV) entry inhibitors targeting spike protein. Virus Res. 194, 200-210. doi: 10.1016/j.virusres.2014.10.007

Yang, Y., Zhang, L., Geng, H., Deng, Y., Huang, B., Guo, Y., et al. (2013). The structural and accessory proteins M, ORF $4 \mathrm{a}$, ORF $4 \mathrm{~b}$, and ORF 5 of Middle East respiratory syndrome coronavirus (MERS-CoV) are potent interferon antagonists. Protein Cell 4, 951-961. doi: 10.1007/s13238-013-3096-8

Yao, Y., Bao, L., Deng, W., Xu, L., Li, F., and Lv, Q. (2014). An animal model of MERS produced by infection of rhesus macaques with MERS coronavirus. J. Infect. Dis. 209, 236-242. doi: 10.1093/infdis/jit590

Yeung, M. L., Yao, Y., Jia, L., Chan, J. F., Chan, K. H., Cheung, K. F., et al. (2016). MERS corona virus induces apoptosis in kidney and lung by upregulating Smad7 and FGF2. Nat. Microbiol. 1:16004. doi: 10.1038/nmicrobiol.2016.4

Ying, T., Li, W., and Dimitrov, D. S. (2016). Discovery of T-Cell infection and apoptosis by Middle East Respiratory Syndrome Coronavirus. J. Infect. Dis. 213, 877-879. doi: 10.1093/infdis/jiv381

Yu, P., Xu, Y., Deng, W., Bao, L., Huang, L., Xu, Y., et al. (2017). Comparative pathology of rhesus macaque and common marmoset animal models with middle east respiratory syndrome coronavirus. PLoS ONE. 12:e0172093. doi: 10.1371/journal.pone.0172093

Zaki, A. M., van Boheemen, S., Bestebroer, T. M., Osterhaus, A. D., and Fouchier, R. A. (2012). Isolation of a novel corona virus from a man with pneumonia in Saudi Arabia. N. Engl. J. Med. 367, 1814-1820. doi: 10.1056/NEJMoa1211721

Zhang, N., Tang, J., Lu, L., Jiang, S., and Du, L. (2015). Receptor-binding domainbased subunit vaccines against MERS-CoV. Virus Res. 202, 151-159. doi: 10. 1016/j.virusres.2014.11.013

Zhang, Z., Shen, L., and Gu, X. (2016). Evolutionary Dynamics of MERSCoV: Potential Recombination, Positive Selection and Transmission. Sci. Rep. 6:25049. doi: 10.1038/srep25049

Zhao, G., He, L., Sun, S., Qiu, H., Tai, W., Chen, J., et al. (2018). A novel nanobody targeting Middle East respiratory syndrome corona virus (MERS-CoV) receptor-binding domain has potent cross-neutralizing activity and protective efficacy against MERS-CoV. J. Virol. 92:e00837-18. e00837-18,PMID:NOPMID doi: 10.1128/JVI.00837-18

Zhao, G., Jiang, Y., Qiu, H., Gao, T., Zeng, Y., Guo, Y., et al. (2015). Multi-organ damage in human dipeptidyl peptidase 4 transgenic mice infected with middle east respiratory syndrome-coronavirus. PLoS One 10:e0145561. doi: 10.1371/ journal.pone.0145561

Zhao, J., Li, K., Wohlford-Lenane, C., Agnihothram, S. S., Fett, C., Zhao, J., et al. (2014). Rapid generation of a mouse model for Middle East respiratory syndrome. Proc. Natl. Acad. Sci. U.S.A. 111, 4970-4975. doi: 10.1073/pnas. 1323279111

Zhao, J., Mangalam, A. K., Channappanavar, R., Fett, C., Meyerholz, D. K., Agnihothram, S., et al. (2016). Airway memory CD4(+) T cells mediate protective immunity against emerging respiratory coronaviruses. Immunity 44, 1379-1391. doi: 10.1016/j.immuni.2016.05.006

Zhou, J., Chu, H., Chan, J. F. W., and Yuen, K. Y. (2015). Middle East respiratory syndrome corona virus infection: virus-host cell interactions and implications on pathogenesis. Virol. J. 12:218. doi: 10.1186/s12985-015-0446-6

Zhou, J., Chu, H., Li, C., Wong, B. H., Cheng, Z. S., Poon, V. K., et al. (2014). Active replication of Middle East respiratory syndrome coronavirus and aberrant induction of inflammatory cytokines and chemokines in human macrophages: 
implications for pathogenesis. J. Infect. Dis. 209, 1331-1342. doi: 10.1093/infdis/ jit504

Ziebuhr, J., Snijder, E. J., and Gorbalenya, A. E. (2000). Virus-encoded proteinases and proteolytic processing in the Nidovirales. J. Gen. Virol. 81(Pt 4), 853-879. doi: 10.1099/0022-1317-81-4-853

Zinzula, L., and Tramontano, E. (2013). Strategies of highly pathogenic RNA viruses to block dsRNA detection by RIG-I-like receptors: hide, mask, hit. Antiviral Res. 100, 615-635. doi: 10.1016/j.antiviral.2013. 10.002

Zumla, A., Hui, D. S., and Perlman, S. (2015). Middle East respiratory syndrome. Lancet 38, 995-1007. doi: 10.1016/S0140-6736(15)60454-8
Conflict of Interest Statement: The authors declare that the research was conducted in the absence of any commercial or financial relationships that could be construed as a potential conflict of interest.

Copyright $\odot 2019$ Skariyachan, Challapilli, Packirisamy, Kumargowda and Sridhar. This is an open-access article distributed under the terms of the Creative Commons Attribution License (CC BY). The use, distribution or reproduction in other forums is permitted, provided the original author(s) and the copyright owner(s) are credited and that the original publication in this journal is cited, in accordance with accepted academic practice. No use, distribution or reproduction is permitted which does not comply with these terms. 